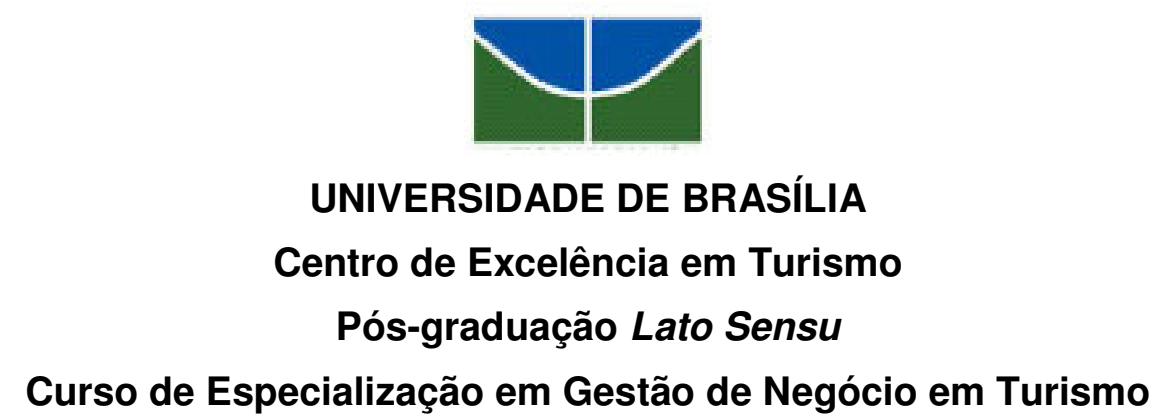

\title{
AÇÕES ESTRATÉGICAS PARA ELABORAÇÃO DE UM PLANO DE NEGÓCIO: ESTUDO DE CASO DE UMA POUSADA EM ALTO PARAÍSO (GO)
}

\author{
DANIEL CALMON PITANGA
}

PROFESSORA ORIENTADORA: Dra. Maria Elenita M. Nascimento 
UNIVERSIDADE DE BRASÍLIA

Centro de Excelência em Turismo

Pós-graduação Lato Sensu

Curso de Especialização em Gestão de Negócio em Turismo

\title{
AÇÕES ESTRATÉGICAS PARA ELABORAÇÃO DE UM PLANO DE NEGÓCIO: ESTUDO DE CASO DE UMA POUSADA EM ALTO PARAÍSO (GO)
}

\author{
DANIEL CALMON PITANGA \\ PROFESSORA ORIENTADORA: Dra. Maria Elenita M. Nascimento
}

Monografia apresentada ao Centro de Excelência em Turismo - CET, da

Universidade de Brasília - UnB, como requisito parcial à obtenção do grau de Especialista em Gestão de Negócio em Turismo

Brasília - 2007 


\section{Centro de Excelência em Turismo}

Pós-graduação Lato Sensu

Curso de Especialização em Gestão de Negócio em Turismo

DANIEL CALMON PITANGA

\section{Aprovado por:}

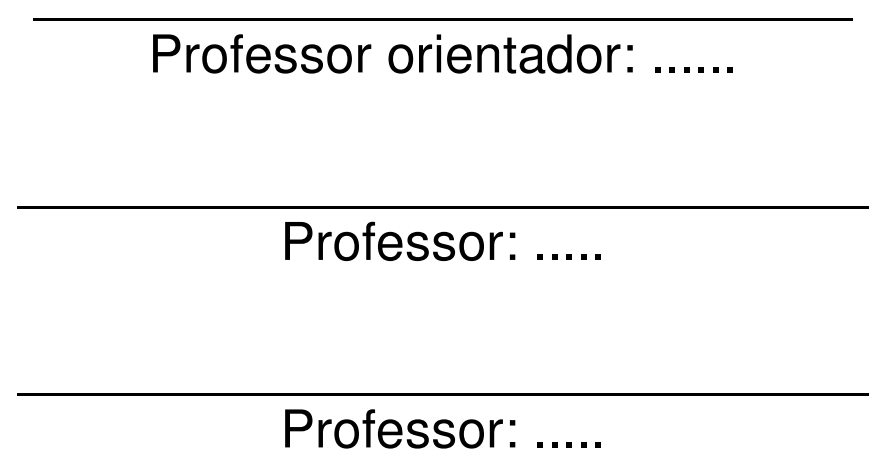

Monografia apresentada ao Centro de Excelência em Turismo - CET, da Universidade de Brasília - UnB, como requisito parcial à obtenção do grau de Especialista em Gestão de Negócio em Turismo

Brasília, ... de ....................de $20 \ldots$. 


\section{RESUMO}

As empresas precisam estar atentas às necessidades do hóspede, seja em uma Pousada ou em um hotel cinco estrelas. A Pousada tem que zelar pela qualidade do descanso de seu hóspede, buscando a melhor forma de agradá-lo com uma boa cama e bons acessórios, além de um local tranqüilo e uma boa refeição para completar. Com estes quesitos básicos o hóspede sente-se bem, pois estão sendo supridas suas necessidades. O restante fica por conta do bom atendimento e da qualidade das instalações. O presente trabalho busca apresentar as ações necessárias para o desenvolvimento de uma Pousada. Como a pesquisa tem caráter descritivo e exploratório foi utilizada pesquisa bibliográfica para o embasamento teórico. Para o estudo de caso foi aplicado um questionário junto aos empreendedores na cidade de Alto Paraíso. Como resultado final obteve-se um plano de negócio para o desenvolvimento da Pousada.

Palavras-chave: 1.Hóspede 2.Pousada 3.Empreendedor 4.Plano de Negócio. 


\begin{abstract}
The Companies need to be intent to the necessities of the guest, either in an inn or a hotel five stars. The inn has that to value for the quality of the rest of its guest, being searched the best form to please it with a good bed and good accessories, beyond a calm place and a good meal to complete. With these basic questions the guest feels itself well, therefore they are being supplied its necessities. The remain is on account of the good attendance and the quality of the installations. The present work searchs to present the necessary actions for the development of an inn. The research has descriptive character having, therefore, been used bibliographical research. For the case study a questionnaire next to the entrepreneurs in the city of High Paradise was applied. As final result got a plan for the development of the Inn
\end{abstract}

Keywords: 1.Guest 2.Inn 3. Entrepreneur 4.Business Plan. 


\section{Lista de Tabelas}

Tabela 4.1 Características das Empresas Entrevistadas

Tabela 4.2 Pontos Fortes e Fracos dos Hotéis

Tabela 5.1 Investimento inicial

Tabela 6.2 Mão-de-obra fixa

61

Tabela 6.3 Mão-de-obra variável

61

Tabela 6.4 Depreciação dos Bens do Imobilizado

Tabela 6.5 Manutenção

Tabela 6.6 Seguro

Tabela 6.7 Custos Fixos, Custos Variáveis E Custos Totais

Tabela 6.8 Capital de Giro

Tabela 6.9 Investimento Total $\quad 69$

Tabela 6.10 Resultados Financeiros, Econômicos e Sociais 70 


\section{Lista de Gráficos}

Gráfico 4.1 Grau de Satisfação dos clientes 45

Gráfico 4.2 Grau de fidelidade dos clientes 45

Gráfico 4.3 Reação dos concorrentes frente à entrada de mais uma

Pousada 46

Gráfico 4.4 O mercado turístico de Alto Paraíso se encontra em qual estágio

Gráfico 4.5 Como classifica a sua Pousada $\quad 47$

$\begin{array}{ll}\text { Gráfico 4.6 Principais canais de distribuição } & 47\end{array}$ 
SUMÁRIO

RESUMO

ABSTRACT

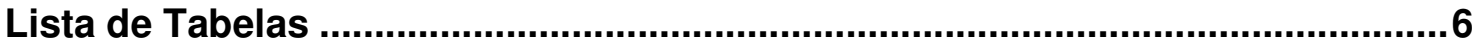

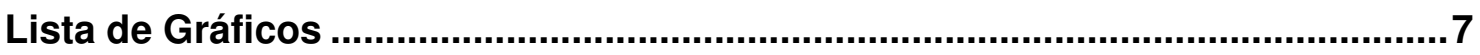

1. INTRODUÇÃO

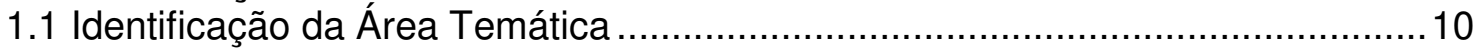

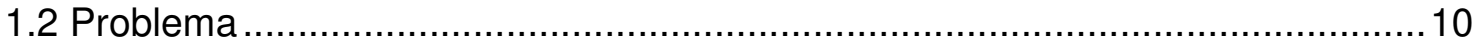

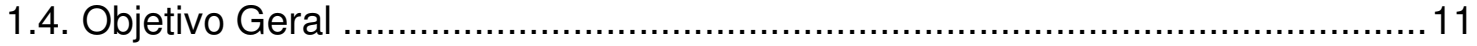

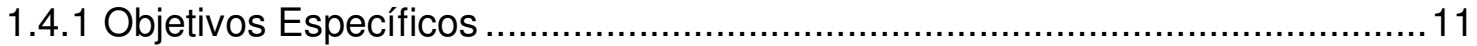

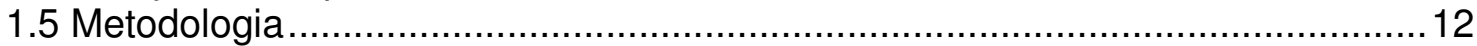

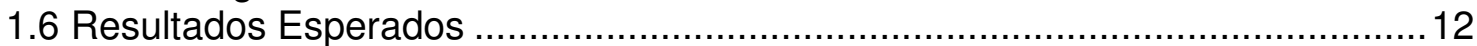

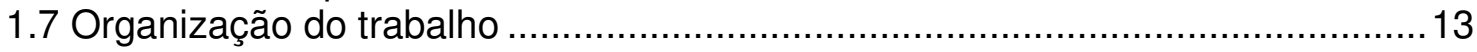

2. ASPECTOS HISTORICOS E CONCEITUAIS ...............................................14

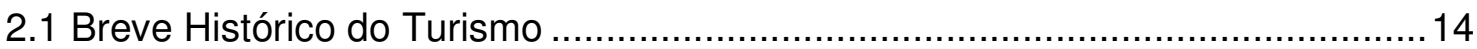

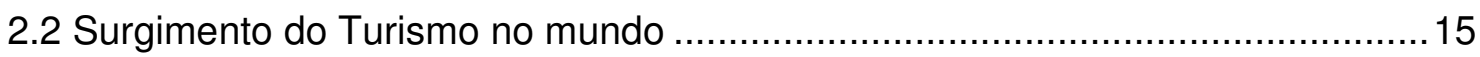

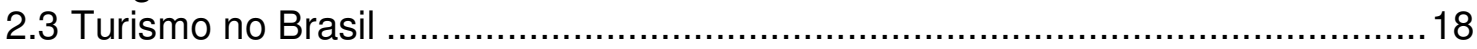

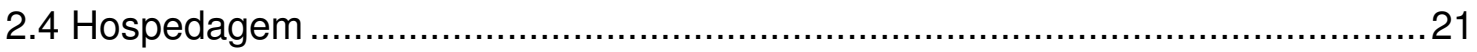

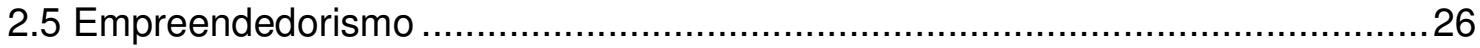

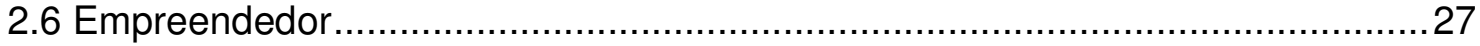



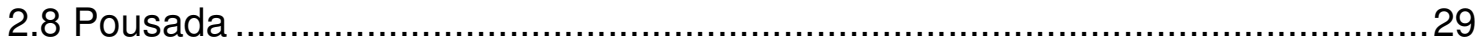

3. PLANEJAMENTO DE UMA POUSADA

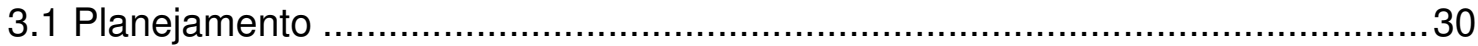

3.2 Aspectos legais para abertura do empreendimento ………….......................32

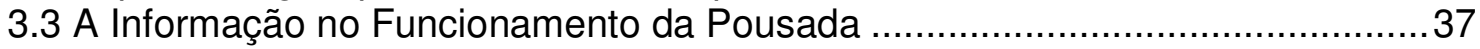

4. ESTUDO DE CASO: POUSADA EM ALTO PARAÍSO .......................................41

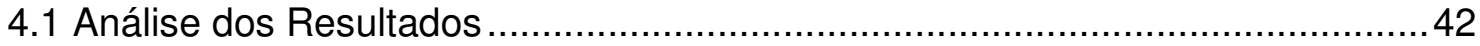

5. PLANO DE NEGÓCIO DA POUSADA PROPOSTA .......................................48

5.1 O Empreendimento ......................................................................... 49

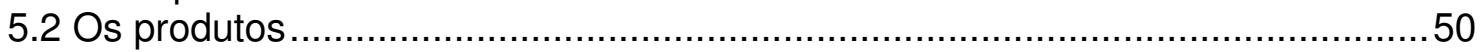

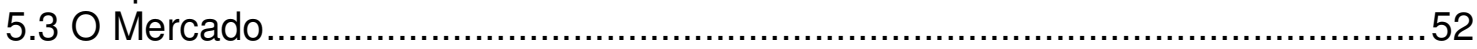

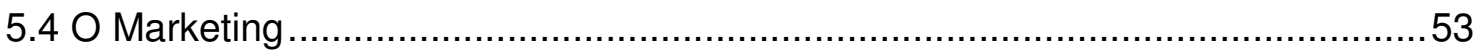

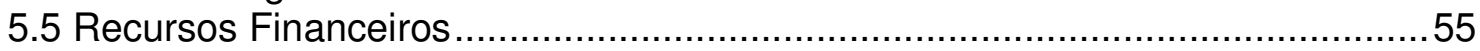

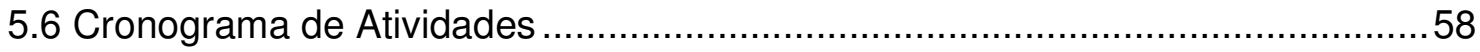




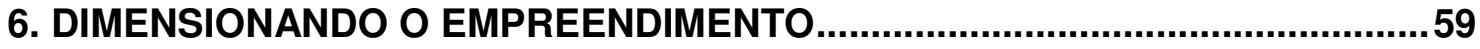

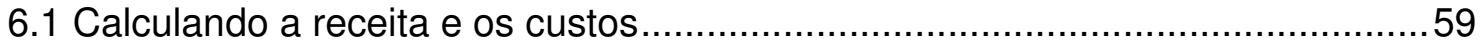

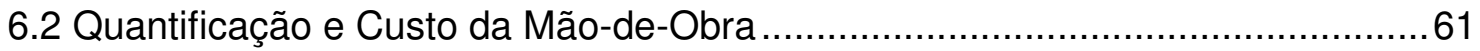

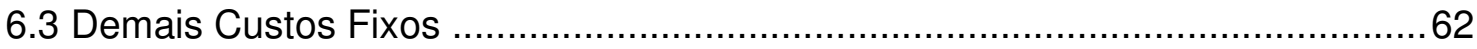

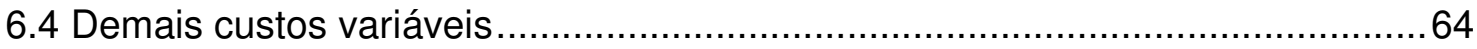

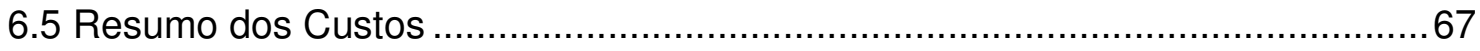

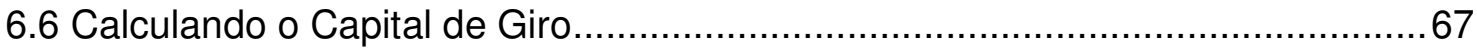

6.7 Definindo o investimento total ............................................................. 68

6.8 Analisando os resultados financeiros, econômicos e sociais ......................... 70

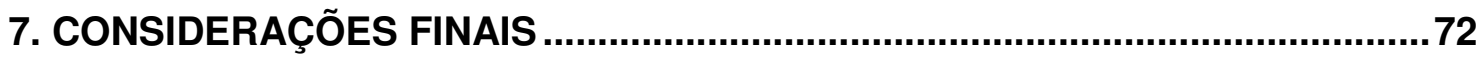

REFERÊNCIAS BIBLIOGRÁFICAS ............................................................... 74

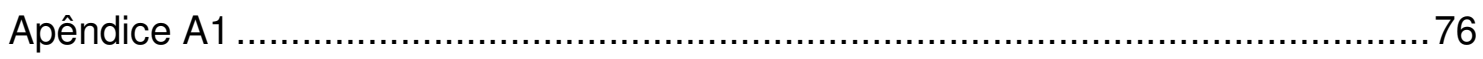



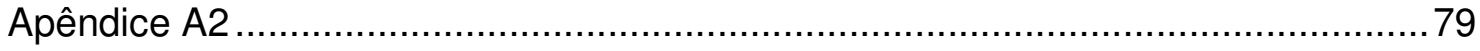

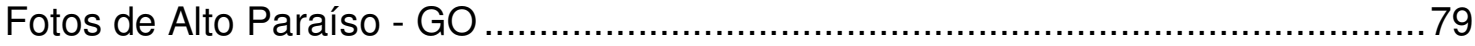

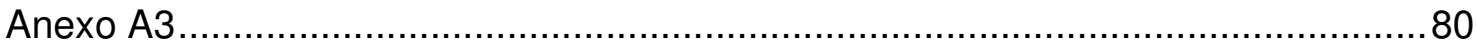

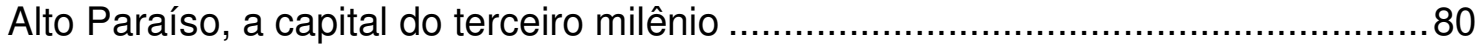




\section{INTRODUÇÃO}

De acordo com a Organização Mundial de Turismo (OMT), Turismo é toda modalidade de deslocamento espacial, que envolve a utilização de algum meio de transporte e pelo menos um pernoite no local de destino.

O conceito de Turismo está sempre em debate, por abranger diversas perspectivas em função da complexidade das relações entre os elementos que o formam.

De acordo com Beltrão (2001), o estudo sobre o assunto vem crescendo, desenvolvendo-se e aperfeiçoando-se ao longo da $2^{\text {a }}$ metade do século XX e início do século XXI.

\subsection{Identificação da Área Temática}

Elaboração de um Plano de Negócio para empreender uma Pousada na cidade turística de Alto Paraíso Goiás (GO).

\subsection{Problema}

O município de Alto Paraíso (vide Apêndice A1) é um dos mais apreciados cartões postais de Goiás. A exuberante natureza esconde cenas quase mágicas, como o pôr do sol, as montanhas, os canyons, as cachoeiras, as minas de cristais, as flores do cerrado e a energia que emana do solo.

O município possui também uma estrutura propícia ao Turismo, com pousadas, hotéis e áreas de camping. Partindo de Brasília pela BR-020, a cidade encontra-se a $222 \mathrm{~km}$ da capital (Anexo A1). No entanto, as pousadas locais deixam a desejar pois não possuem muitos atrativos, necessitando de reformas e inserção de outros benefícios. Tais problemas nos levam a levantar as seguintes questões: Valeria a pena empreender mais uma pousada na cidade de Alto Paraíso? Em caso positivo que características diferenciadoras seriam importantes serem incorporadas 
para torná-la competitiva nesse mercado? Este trabalho de pesquisa visa responder essas questões.

\subsection{Justificativa}

A justificativa para escolha do tema tem como base três pontos fundamentais: a) do ponto de vista, acadêmico, servir de fonte de pesquisa para futuros trabalhos dessa natureza; b) do ponto de vista de mercado reduzir os riscos do empreendimento e como conseqüência aumentar as condições de sobrevivência no mercado; c) do ponto de vista do projeto a possibilidade de ser realizado na prática requerer a elaboração de um Plano de Negócio.

\subsection{Objetivo Geral}

Apresentar as ações necessárias para elaboração de um Plano de Negócio, com o fim de estruturar uma Pousada na cidade de Alto Paraíso.

\subsubsection{Objetivos Específicos}

- Estruturar as principais ações para decidir sobre a viabilidade do empreendimento, no caso uma Pousada;

- $\quad$ Analisar as oportunidades do Mercado;

- Elaborar o Plano de Marketing e o Plano Financeiro;

- Apresentar o Plano de Negócio tendo como estudo de caso, a Pousada no município de Alto Paraíso. 


\subsection{Metodologia}

Por se tratar de um estudo qualitativo do segmento de Turismo receptivo, essa pesquisa apresenta caráter descritivo e exploratório. $\mathrm{O}$ que se pretende é identificar a correlação entre as variáveis: Turismo, Turismo receptivo, Turismo de negócio em Alto Paraíso (GO). O levantamento dessas variáveis irá definir se é economicamente viável a construção de uma Pousada na cidade turística de Alto Paraíso (GO).

A seção 4 tratará sobre o estudo de caso objeto desta pesquisa que é a proposta de um Plano de Negócio para a construção de uma Pousada em Alto Paraíso - GO.

Os principais meios de investigação utilizados neste estudo são: pesquisa bibliográfica e pesquisa de campo. A pesquisa bibliográfica será desenvolvida com base em material publicado em livros, artigos e outras fontes de consulta, como a Internet. Os levantamentos documentais fornecem informações referentes a cidade turística de Alto Paraíso. Tais informações são levantadas em documentos, manuais, estatuto e regulamentações que possibilitam a caracterização geral do objeto em estudo.

Para a pesquisa de campo foi elaborado um questionário contendo questões abertas e fechadas, que foi aplicado junto aos 4 proprietários de quatro Pousadas na cidade turística de Alto Paraíso - GO, (vide Apêndice A1). O objetivo do questionário foi identificar se a cidade apresenta potencial turístico e se recebe uma boa demanda de turistas durante o ano.

\subsection{Resultados Esperados}

Como resultado da pesquisa espera-se estruturar as ações estratégicas necessárias para o desenvolvimento de uma Pousada, evitando-se assim, os riscos de empreender sem planejar. 


\subsection{Organização do trabalho}

Este trabalho está organizado da seguinte forma: a primeira seção faz uma introdução onde são apresentados a área temática, o problema, a justificativa do estudo e os objetivos propostos, a metodologia e os resultados esperados.

Na seção 2 serão descritos os aspectos históricos e conceituais, tais como um breve histórico do Turismo, o surgimento do Turismo no mundo e no Brasil, além dos conceitos de empreendedorismo, de empreendedor, plano de negócio e o conceito de Pousada.

Na seção 3 será descrito o planejamento de uma Pousada bem como seus aspectos legais e a importância da Tecnologia da Informação para seu funcionamento.

A seção 4 apresenta o estudo de caso: Pousada em Alto Paraíso, que é objeto desta pesquisa.

Na seção 5 será apresentado o Plano de Negócio da Pousada proposta apontando o empreendimento, os produtos, o mercado, o marketing, os recursos financeiros e o cronograma de atividades.

O trabalho inclui ainda dois Apêndices e um Anexo. O Apêndice A1 apresenta o questionário aplicado junto aos proprietários das Pousadas; o Apêndice A2 apresenta algumas fotos do local e o Anexo A1 mais informações sobre a cidade de Alto Paraíso - GO. 


\section{ASPECTOS HISTORICOS E CONCEITUAIS}

Esta seção trata dos aspectos históricos e conceituais do Turismo no Brasil e apresenta os conceitos de empreendimento, empreendedorismo, hospedagem, Plano de negócio e Pousada que são objeto deste trabalho.

\subsection{Breve Histórico do Turismo}

Segundo Beltrão (2001) os Jogos Olímpicos que ocorreram em 776 a.C, na Grécia, constituíram o marco do inicio do Turismo. Os Fenícios e Romanos prestaram suas contribuições e foram os primeiros, com a invenção da moeda e do comércio, facilitando as viagens. O segundo com a construção de estradas encurtando as distâncias das viagens e a construção de obras, como hospedarias, nas margens do mesmo.

Entre os séculos II e III, com a construção do Santo Sepulcro pelo Imperador Constantino em 326 d.C houve intensa peregrinação à Jerusalém. A partir do século VI, cristãos, peregrinavam para Roma e Jerusalém, e os Mometanos para Meca. A tomada de Jerusalém pelos Turcos, coincidiu com a descoberta da tumba de Santiago de Compostela, na Espanha, no século IX. Tais fatos contribuíram para o aumento das viagens na Espanha. As Cruzadas contribuíram para o deslocamento de viajantes, soldados e mercadores pelo território Europeu. O livro de Marco Polo, Le Livre de Marco Polo, foi considerada uma das mais importantes obras do século XIII, na Europa, estimulando viagens à Ásia.

Segundo Beltrão (2001) no final do século XVIII, com a Europa em paz, houve um aumento das viagens de Turismo. A necessidade de agilizar as correspondências levou a formação de diligências, que levava, também, alguns passageiros. Em 1830 com a construção da ferrovia Liverpool-Manchester houve aumento das viagens e consequentemente do Turismo. Em 1841, Thomas Cook, considerado o "pai do Turismo", fundou a primeira Agência de Viagem do mundo, utilizando largamente trens e navios. Ainda no século XIX, vários fatores contribuíram para o aumento do Turismo, por exemplo: a Revolução Industrial, 
cidades com água e esgoto tratados, o direito dos trabalhadores a férias remuneradas e a diminuição do analfabetismo.

No início do século XX (1915), a Inglaterra começou a controlar os turistas através do passaporte. Em 1929, foi inaugurado o primeiro Free Shop do mundo, no aeroporto de Amsterdã (Holanda). Durante a Segunda Guerra Mundial não ocorreu o Turismo. Contudo, após a guerra o Turismo passa a tomar impulso, principalmente a partir de 1949, quando foi criado o primeiro pacote turístico utilizando o avião como meio de transporte.

Segundo Beltrão (2001) na segunda metade do século $X X$, os europeus do Norte procuravam, no inverno, regiões menos frias, cujas temperaturas fossem mais elevadas, como Nice, Saint Tropez e Cannes. Em 1970, já havia grande concorrência entre os meios de transporte, entre as cadeias hoteleiras, entre as Agências de Viagem e Companhias Aéreas. Com isso, houve redução das tarifas, incrementando ainda mais o Turismo. Com a invenção dos computadores, a partir de 1980 se conseguia saber, pela internet, preços de hotéis, das passagens, de aluguel de veículos, levando a diminuição ainda maior dos pacotes turísticos. Ao final do século $X X$, aviões eram capazes de transportar até 400 passageiros, com autonomia de vôo de ate 15 horas.

\subsection{Surgimento do Turismo no mundo}

Segundo Trigo (2002) o Turismo organizado surgiu a partir de meados do século XIX, como conseqüência do desenvolvimento tecnológico iniciado pela Revolução Industrial e pela formação de parcelas da burguesia comercial e industrial com tempo, dinheiro e disponibilidade para viajar.

A tecnologia do final do século XIX possibilitou novas construções em ferro fundido, como torres (Torre Eiffel, em Paris), estações ferroviárias, grandes salões com estruturas livres de ferro para sediar exposições ou realizar bailes e grandes edifícios ou arranha-céus. Essas novas possibilidades de engenharia começaram a mudar a aparecia das grandes cidades no mundo, assim como meios de transportes. 
O referido autor afirma ainda que dois meios de transportes importantes foram desenvolvidos nessa fase, ambos construídos em ferro e aço e adotados de motores a propulsão com base no vapor de água. Esses novos meios de transportes foram os navios de passageiros e de trens. Os imensos navios a vela, com grande sofisticação e luxo, passam a ser cada vez mais utilizados nas viagens intercontinentais, transportando os novo-ricos beneficiados pela indústria, comercio e finanças mundiais.

O trem substituiu a diligencia, evitando assim os desconfortos causados pela poeira das estradas na época das chuvas e pela nevasca de inverno. $O$ trem desloca-se em trilhos de ferro com maior segurança e rapidez, movido por possantes motores a vapor que consomem a lenha das florestas próximas ás linhas e a água dos rios para refrigerar a caldeira. A primeira linha férrea foi construída por Stephenson em 1825, ligando Stockton a Darlington, no Reino Unido. O crescimento das ferrovias foi muito rápido. Em 1869, os Estados Unidos já estavam interligados através de duas grandes linhas: a Union Pacific e a Central Pacific Ogden. Antes da primeira guerra mundial (1914-1918), A Europa já possuía 415 mil km de ferrovias e os Estados Unidos, 410 mil Km. As linhas férreas de maior importância no mundo são: Transiberiano, de Cheliavinsk, com 6.550 km, Southem Pacific Railway. De Halifax a Vancouver, com 6.028 K, Australian Coast, de Brisbane a Perth, via Melbourne e Port Augusta, com 5.600 km, Cidade do Cabo ao Cairo, com 9.500 km, Orient Express, de Paris a Bucarest, com 3.165 km.

Segundo Trigo (2002) O Turismo no século XIX era caracterizado como residencial, ou seja, as pessoas ficavam um período ou uma estação do ano em uma segunda residência. A viagem ou temporada, era motivada por questões de saúde, clima, descanso das atividades rotineiras do ano e durava de poucas semanas a dois a três meses. Havia o Turismo residencial termal, que era dirigido ás estações de água européias, precursoras dos modernos "spas". A partir de 1860 inicia-se na cidade de Monte Carlo, a época dos cassinos, inspirados em luxuosos salões de grandes hotéis.

Para Trigo (2002) no final do século XVIII surge, na Europa, um movimento turístico de verão com destino as montanhas, especialmente aos Alpes suíços. Essa modalidade recebe o nome de paisagismo e provoca, já em 1828, a chegada de 50.000 turistas estrangeiros a genebra, na Suíça. Ao lado do agradável descanso 
nas paisagens montanhosas, aparece o desejo de aventura, marcado pelas escaladas esportivas dos cumes rochosos. Em 1857, é fundado o clube britânico de alpinismo; em 1863, surgem os clubes italianos, austríacos e suíços; e, em 1874, o clube francês. $O$ desejo de estar próximo à natureza também aparece na América do Norte.

Em 1872, é criado o Parque Nacional de Yellowstone (Wyoming, Montana Idaho), o primeiro do mundo. Em 1873, o governo canadense cria o Parque Nacional de Banff, nas encostas orientais das Montanhas Rochosas, na província de Alberta.

Em 1869, é fundada na Suíça a União Internacional dos Hoteleiros, e em 1889, é inaugurado o teleférico de Monte Pilatos, também na Suíça. Até então as viagens aos Alpes eram realizadas quase que exclusivamente durante o período de verão. A partir de 1992 iniciam-se as férias de inverno. Começas a Surgir estações de esporte e inverno (Esqui, trenó) nos Alpes e nos Pirineus na fronteira entre França e Espanha.

Outra região natural importante para atrais turistas é o mar. Desde 1845, a praia de San Sebastián, na Espanha, atrai visitantes importantes como a Rainha Isabel II. Na França, na mesma época, a imperatriz Eugênia começa a freqüentar as praias de Birrtiz. O primeiro Palace Hotel litorâneo foi construído em Nice, em 1883, e até o final do século XIX, nas praias quentes no sul da Europa, à beira do mediterrâneo, surgem hotéis, cassinos e vilas de veraneio.

Segundo Trigo (2002) o escritor alemão Thomas Mann mostra a vida nesses recantos em dois de seus romances: A montanha mágica descreve o cotidiano nos luxuosos sanatórios para tuberculosos, nos Alpes, por volta de 19101914; e morte em Veneza tem como cenário o veraneio no norte as Itália, também no inicio do século XX. Algumas datas importantes na história do Turismo: 1840Surge a agência Abreu, no Porto, em Portugal; 1841- Primeira excursão organizada por Thomas Cook, no Reino Unido; em 1878- Funcionam cerca de 250 agências de viagem em todo o mundo; 1882- a Arican Express Company lança o money order, que antecedeu o cheque de viagem.

O crescimento do Turismo na Europa é interrompido pela Primeira Guerra Mundial e retomado em 1919. O ano de 1929 pode ser indicado como o ano do crescimento do Turismo Europeu, quando a Suíça recebeu 2.209.000 visitantes 
estrangeiros. A crise iniciada no mesmo ano, com a queda da Bolsa de Valores de Nova York, reflete-se no mundo todo e atinge a Europa em 1932, causando uma segunda estagnação do Turismo em sua curta história. No século $X X$. A nova ascensão acontece no final da década de 1930 e atinge seu auge no ano de 1937. A Espanha não participa desse novo surto devido aos conflitos gerados pela Guerra Civil (1936-1939). No final da década, o Turismo começa ter progressivas instabilidades políticas causadas pelos regimes fascistas, na Itália, e nazistas, na Alemanha. Com a Segunda Guerra mundial (1939-1945), o Turismo fica paralisado no mundo todo. Os efeitos da guerra são tão profundos que somente em 1949 o Turismo renasce, então com características crescentes de Turismo de massa.

Segundo Trigo (2002) foi um período de grande crescimento da indústria de Viagens nos países mais ricos e industrializados do mundo. Os transportes e outras formas de comunicação, em especial a televisão, reforçam ainda mais os fatores econômicos que favorecem a expansão do Turismo, com propagandas constantes sobre os interesses e as variedades de atrações dos países estrangeiros. Gradualmente, o apelo comercial pelos destinos internacionais superou o interesse pelo produto interno e pela vontade de ficar em casa. Nos países mais ricos, a população passou a viajar mais. As empresas automobilísticas expandiram estrondosamente. Os registros do numero de carros em todo o mundo mostraram um crescimento de 110 milhões, em 1970, para 394 milhões em 198. Só na Europa, a quantidade de carros chegou a mais que o dobro nesse período, passando de 68 milhões para 159 milhões, um aumento de cerca de 135\%. Segundo a Organização para Cooperação e Desenvolvimento Econômico (OCDE), os carros particulares eram responsáveis por $80 \%$ do transporte no interior do país (passageiro quilometro).

\subsection{Turismo no Brasil}

O século XIX trouxe ao Brasil uma nova era de aproximação com o mundo, conforme Trigo (2002). Neste sentido, a vinda da Família Real e a Abertura dos Portos mais uma vez poderiam representar um divisor de águas na questão da presença de viajantes estrangeiros. As novas condições exigidas pela situação de sede do reino não deixaram, de abrir nossas portas à curiosidade mundial. Com a 
volta da paz à Europa depois de 1815, numerosas viagens ao Brasil foram executadas. O Rio de Janeiro, mais do que qualquer outra localidade brasileira, já apresentava condições suficientes para ser um ponto de estada nos roteiros das embarcações que percorriam o mundo, seja pela sua situação ou pela presença do seu porto, seja pelo relativo desenvolvimento conseguido com a presença do rei. Dessa forma muitas naus empreenderam viagens nas quais incluíam o Brasil no trajeto. De 1817 a 1839 são conhecidos entre outros, os seguintes relatos desse tipo de viagem no interesse das Ciências e da Navegação.

As grandes viagens ao redor do mundo ou expedições científicas que envolviam diversos países para serem visitados foram responsáveis apenas por uma parte da presença de viajantes no Brasil. A relação dos que visitaram as terras brasileiras, só no século XIX, é extensíssima e, ao que parece, ainda não inteiramente concluída. Limito-me a constatar o fato de que são raríssimos os exemplos do que vinham simplesmente para conhecer o Brasil nos moldes daquilo que poderíamos chamar de Turismo moderno. Apenas para ficar entre os viajantes mais conhecidos, o que ganha maior relevo quanto à finalidade da viagem é o interesse científico, característica, aliás, da época, expressa na existência de grande numero de Academias de Ciências na Europa.

Segundo Trigo (2002) embora numericamente majoritário, os cientistas não foram os únicos. Muito conhecidos ficaram também os artistas, principalmente os pintores que vieram na sua maioria em missões artísticas ou acompanhando expedições de natureza científica. Nessa categoria vieram o pintor alemão Johann Moritz Rugendas e o francês Hercules Florence, contratados para a expedição de Langsdorff ao interior do Brasil. Não menos famoso o pintor francês Jean Baptiste Debret, que veio na missão artística contratada em 1816 para fundar a escola de Belas Artes do Rio de Janeiro. O Austríaco Thomas Ender, por sua vez, visitou-nos acompanhando a comitiva da Arquiduquesa Leopoldina. O francês François Auguste Riard veio, ao que parece, por sua própria iniciativa. As possibilidades comercias que se estenderam a partir da Abertura dos Portos, trouxeram também homens desejosos de enriquecer nessa atividade. Quase que abrindo esta relação, vemos o comerciante inglês John Luccock, que veio logo após o Ato de Abertura dos Portos. Também ingleses eram John Mawe que além de comerciante era mineralogista e Heny Koster.Entre os franceses incluem-se Arséne Isabelle e L.F.Tollenare. 
O mesmo autor enfatiza que em uma terra carente de mão-de-obra especializada, engenheiros vieram para construção de obras específicas. É o caso do oficial de artilharia e engenheiro militar português Luiz L'Alincurt; do inglês Thomas Bigg-Whither, que explorou o noroeste do Paraná com o objetivo de traçar uma estrada de ferro; do francês Louis Léger Vauthier e do norte-americano Neville B. Craig, este já no final do século. O conjunto das atividades que vieram exercer no Brasil torna-se mais claro quando constatamos a presença de jornalistas. É o caso do português Emílio Augusto Zaluar ou do Francês Max Leclerc, mandando ao Brasil pelo journal dês Débats logo após a Proclamação da República.

O referido autor aponta que alguns não mereciam ser chamados propriamente de viajantes, como os exilados: Charles Ribeyrolles residiu no Brasilaté seu falecimento; ou como o colono suíço Thomas Davatz, autor de importante obra sobre as condições de vida dos colonos suíços na Fazenda ibicaba, pertencente ao senador Nicolau Vergueiro. Encerrando essa incompleta relação, temos as professoras e os professores, como a alemã Ina von Binzer ou o professor francês Charles Expilly. A idéia de deleite ou do simples prazer da viagem não era o motivo que traziam esses viajantes ao Brasil. Os que mais se parecem com turistas modernos é o Diplomata francês Henri Allizé que, embora não tenha servido no Brasil, esteve aqui a passeio no início de sua carreira, em dois meses de recreação no ano de 1886 e, antes dele, a inglesa Marianne North. Essa, nascida em uma família de nobres, políticos e intelectuais, estava acostumada a viajar desde menina, quando percorreu o mundo com a família. Depois de mortos os pais, solteira, começou a se aventurar sozinha por terras cada vez mais incógnitas até que, em 1872, aos 42 anos de idade, resolveu realizar um sonho antigo: conhecer o Brasil.

Segundo Trigo (2002) No decorrer, pois, do século XIX, avolumaram-se os relatos sobre o Brasil, em virtude do grande afluxo de viajantes estrangeiros que para cá veio, principalmente, a partir da Abertura dos portos.

Para o referido autor, nesse século, embora não mais interessados nas lendas fabulosas de antigamente, ainda são muitos os aspectos exóticos descritos nessas obras que reforçam a visão, já existente, que o europeu teve ou ainda tem de uma terra pitoresca e estranha. Treze dessas obras foram quase todas publicadas ainda no século XIX, com exceção de algumas, como a de Henry Allizé ou a de Louis Léger Vauthier. Outras tiveram publicação na língua original do 
viajante, recebendo publicação em português apenas no século $X X$, como a de Francis de Castelnau, em 15 volumes, cuja parte referente ao Brasil data de 1949 a publicação. Alguns viajantes separavam as anotações científicas das quais se utilizavam para a publicação de monografias específicas das de viagem propriamente ditas, cuja organização resultava na publicação de livros de viagens propriamente ditas, cuja organização resultava na publicação de livros de viagens. É o caso de Hermann Burmeister que, além de diversas obras a fauna brasileira, publicou seu Viagem ao Brasil através das Províncias do Rio de Janeiro e Minas Gerais. Por fim, caberia dizer que nem sempre são concordantes os relatos desses estrangeiros que percorreram o Brasil no século passado.

\subsection{Hospedagem}

De acordo com o inciso IV, do artigo 11 da Deliberação Normativa 387/98 (revogada pela Deliberação Normativa 429/02), considerava-se pousada, todo o meio de hospedagem de aspectos arquitetônicos e construtivos, instalações, equipamentos e serviços simplificados, normalmente limitados, apenas, ao necessário à hospedagem do turista para aproveitamento do atrativo turístico junto ao qual o estabelecimento se situa.

A Deliberação Normativa 429/02 não define pousada, porém, considerandose o conceito da Deliberação Normativa 387/98 (ora revogada), verifica-se que pousada, tratar-se-á de um meio de hospedagem, portanto, a pousada deverá atender os requisitos mínimos fixados na mencionada Deliberação Normativa 429/02, ou seja, considera-se meio de hospedagem o estabelecimento que satisfaça, cumulativamente, às seguintes condições:

I - seja licenciado pelas autoridades competentes para prestar serviços de hospedagem;

II - seja administrado ou explorado comercialmente por empresa hoteleira considera-se empresa hoteleira a pessoa jurídica, constituída na forma de sociedade anônima ou sociedade por quotas de responsabilidade limitada, que explore ou administre meio de hospedagem e que tenha em seus objetivos sociais o exercício de atividade hoteleira - e que adote, no relacionamento com 
os hóspedes, contrato de hospedagem, com as características definidas neste Regulamento e nas demais legislações aplicáveis.

Os meios de hospedagem oferecerão aos hóspedes, no mínimo:

I - alojamento, para uso temporário do hóspede, em unidades habitacionais - o espaço, atingível a partir das áreas principais de circulação comuns do estabelecimento destinados à utilização pelo hóspede, para seu bem-estar, higiene e repouso - específicas a essa finalidade;

II - serviços mínimos necessários ao hóspede, consistentes em:

a) Portaria/recepção para atendimento e controle permanentes de entrada e saída;

b) Guarda de bagagens e objetos de uso pessoal dos hóspedes, em local apropriado;

c) Conservação, manutenção, arrumação e limpeza das áreas, instalações e equipamentos.

III - padrões comuns estabelecidos neste Regulamento.

Os padrões comuns a todos os meios de hospedagem são os seguintes:

I - Quanto a posturas legais:

a) licenciamento pelas autoridades competentes para prestar serviços de hospedagem, inclusive dos órgãos de proteção ambiental;

b) administração ou exploração comercial, por empresa hoteleira;

c) oferta de alojamento temporário para hóspedes, mediante adoção de contrato, tácito ou expresso, de hospedagem e cobrança de diária, pela ocupação da unidade habitacional; 
d) exigências da legislação trabalhista, especialmente no que se refere a vestiários, sanitários e local de refeições de funcionários e Comissões de Prevenção de Acidentes de Trabalho - CIPA.

II - Quanto aos aspectos construtivos:

a) edificações construídas ou expressamente adaptadas para a atividade;

b) áreas destinadas aos serviços de alojamento, portaria/recepção, circulação, serviços de alimentação, lazer e uso comum, e outros serviços de conveniência do hóspede, ou usuário separadas entre si e, no caso de edificações que atendam a outros fins, independentes das demais;

c) proteção sonora, conforme as normas da Associação Brasileira de Normas Técnicas - ABNT - e legislação aplicáveis;

d) salas e quartos de dormir das unidades habitacionais dispondo de aberturas para o exterior, para fins de iluminação e ventilação;

e) todos os banheiros dispondo de ventilação natural, com abertura direta para o exterior, ou através de duto;

f) serviços básicos de abastecimento de água que não prejudiquem a comunidade local, bem como de energia elétrica, rede sanitária, tratamento de efluentes e coleta de resíduos sólidos, com destinação adequada;

g) facilidades construtivas, de instalações e de uso, para pessoas com necessidades especiais, de acordo com a NBR 9050 - 1994, em prédio com projeto de arquitetura aprovado pela Prefeitura Municipal, como meio de hospedagem, após 12 de agosto de 1987.

Em caso de projetos anteriores, o meio de hospedagem deverá dispor de sistema especial de atendimento. 
III - Quanto a equipamentos e instalações:

a) instalações elétricas e hidráulicas de acordo com as normas da Associação Brasileira de Normas Técnicas - ABNT - e legislação aplicável;

b) instalações de emergência, para a iluminação de áreas comuns e para o funcionamento de equipamentos indispensáveis à segurança dos hóspedes;

c) elevador para passageiros e cargas, ou serviço, em prédio com quatro ou mais pavimentos, inclusive o térreo, ou conforme posturas municipais;

d) instalações e equipamentos de segurança contra incêndio e pessoal treinado a operá-lo, de acordo com as normas estabelecidas e pelo Corpo de Bombeiros local;

e) quarto de dormir da unidade habitacional mobiliado, no mínimo, com cama, equipamentos para a guarda de roupas e objetos pessoais, mesa-decabeceira e cadeira.

IV - Quanto aos serviços e a gestão:

a) portaria/recepção apta a permitir a entrada, saída, registro e liquidação e conta dos hóspedes, durante as 24 horas do dia;

b) registro obrigatório do hóspede no momento de sua chegada ao estabelecimento, por meio de preenchimento da Ficha Nacional e Registro de Hóspedes - FNRH, aprovada pela EMBRATUR;

c) limpeza e arrumação diária da unidade habitacional, fornecimento troca de roupa de cama e banho, bem como de artigos comuns e higiene pessoal, por conta do estabelecimento;

d) serviços telefônicos prestados aos hóspedes de acordo com os regulamentos internos dos estabelecimentos e as normas e procedimentos adotados pelas concessionárias dos serviços, ou pelo poder concedente;

e) imunização, permanente contra insetos e roedores; 
f) pessoal de serviço em quantidade e com a qualificação necessária o perfeito funcionamento do meio de hospedagem;

g) pessoal mantido permanentemente uniformizado e/ou convenientemente rajado, de acordo com as funções que exerçam;

h) meios para pesquisar opiniões e reclamações dos hóspedes e solucioná-las;

i) observância das demais normas e condições necessárias à segurança, saúde/higiene e conservação/manutenção do meio de hospedagem, para atendimento ao consumidor.

Observe-se que nas localidades não servidas ou precariamente servidas por redes de serviços públicos, a satisfação dos itens obrigatórios, cujo atendimento dependa da existência dessas redes, será apreciada, caso a caso, pela EMBRATUR.

Serão exigidas condições específicas de proteção, observando-se as normas e padrões estabelecidos pelos órgãos governamentais competentes, para os meios de hospedagem localizados no interior ou nas proximidades de:

a) unidades de conservação, ou protegidas pela legislação ambiental vigente;

b) aeroportos, estações viárias, vias industriais, ou estabelecimentos que ofereçam problemas especiais de poluição ambiental e sonora.

Quanto às portas entre unidades habitacionais conjugáveis, estas deverão dispor de sistema que somente possibilite sua abertura, quando por iniciativa mútua dos ocupantes de ambas as unidades.

A Deliberação Normativa 429/02, regulamenta todo e qualquer tipo de hospedagem, a integra pode ser encontrada no site da EMBRATUR, a saber, www.embratur.gov.br, no link legislação, meios de hospedagem, Deliberações Normativa. 


\subsection{Empreendedorismo}

Segundo Shumpeter (1997), convém ressaltar a consciência e sustentabilidade das empresas, as quais não só o comportamento do empresário como, também, as práticas gerenciais na condução dos negócios, a qualidade dos produtos e serviços oferecidos, que situação econômica e a estrutura tributária do país.

Pesquisa do Serviço Brasileiro de apoio á Micro e Pequenas Empresas (SEBRAE 2005) revela que no Brasil, a pequena empresa representa $98,5 \%$ das empresas existentes no país, $60 \%$ da oferta de emprego e $21 \%$ do Produto Interno Bruto (PIB). O índice de mortalidade destas empresas é alto devido a fatores como: habilidade gerencial, conhecimento do mercado, uma boa estratégia de vendas, capacidade empreendedora, aproveitamento das oportunidades de negócio, perseverança, capacidade de liderança e logística operacional representada por escolha de um bom administrador entre outros.

Uma característica marcante entre os empreendedores e descrito por muitos autores trata-se da inovação, ou seja, do instrumento especifico dos empreendedores, eles exploram a mudança como uma oportunidade para negócios ou serviços diferentes, podendo ser aprendida e praticada.

Para Filion (1991), "o empreendedor é o inovador com características que compreendem criatividade, persistência, liderança, iniciativa, flexibilidade em conduzir situações e habilidade em utilizações de recursos.".

O empreendedorismo, portanto, é um conceito dinâmico, e o empreendedor destaca-se ou mesmo surge quando novas situações aparecem, e novas decisões são tomadas e novos rumos são escolhidos.

Conforme Flilon (1991), por ser simples e abrangente um empreendedor e uma pessoa que imagina, desenvolve e realiza visões. 


\subsection{Empreendedor}

Com base nas pesquisas de Timmos \& Hornaday (1994; 1982), serão apresentados a seguir uma síntese das principais características de um empreendedor de sucesso.

O empreendedor geralmente tem um "modelo", ou seja, uma pessoa que o influencia, tem iniciativa, autonomia, autoconfiança, otimismo e necessidade de realização. Geralmente trabalha sozinho com perseverança e tenacidade; o fracasso é considerado um resultado como outro qualquer, ou seja, aprende com os resultados negativos, com seus próprios erros; tem grande energia e capaz de se dedicar intensamente ao trabalho e sabe concentrar os seus esforços para alcançar resultados, ou seja, sabe fixar metas e alcançá-las.

Todo empreendedor tem uma visão do seu empreendimento e segundo a teoria de Filion (1991) essa visão os ajuda a entender como se forma uma idéia de produto e quais as condições para que ele surja. As pessoas motivadas a abrir uma empresa vão criando, no decorrer do tempo, baseadas na sua experiência, idéia de produtos. Tais idéias a princípio, emergem em estado bruto e reflete ainda um sonho, uma vontade não muito definida, ou seja, ainda não sofreram um processo de validação, podem ainda não ser um produto. Para Filion, essas idéias iniciais são visões emergentes, prosseguindo em sua busca, vai chegar um dia em que o empreendedor sente que encontrou a forma final do produto e já sabe para quem vai vendê-lo. Nesse momento ele acaba de dar corpo a sua visão central, ou seja, tem um produto bem definido e sabe qual e o mercado para ele.

\subsection{Plano de Negócio}

Segundo Felipini (2004) "Um Plano de Negócios é basicamente um instrumento de planejamento, no qual as principais variáveis envolvidas em um empreendimento são apresentadas de forma organizada."

Um Plano de Negócio é um documento pelo qual o empreendedor formalizará os estudos a respeito de suas idéias, transformando-as em um 
NEGÓCIO. No Plano de Negócios deve ser registrado o conceito do negócio, os riscos, os concorrentes, o perfil da clientela, as estratégias de Marketing, bem como todo o plano financeiro que viabilizará o novo negócio. Além de ser um ótimo instrumento de apresentação do negócio para o empreendedor que procura sócio ou um investidor.

O Plano de Negócios não tem um caráter estático, mas sim, dinâmico. Na medida em que haja mudanças do cenário do mercado, da economia, da tecnologia ou das ações dos competidores, deve ser feita uma revisão. Isso em geral requer uma revisão semestral do plano, mas, dependendo do tipo de negócio e da situação do mercado, é necessário fazer essa revisão em períodos maiores ou menores.

Sem fazer uma revisão periódica do Plano de Negócios o empreendedor não estará acompanhando a evolução do mercado, de seus competidores, da situação econômica e tecnológica.

Obviamente, o processo de fazer planos para a criação de um novo negócio, sempre existiu, mesmo que de forma empírica ou somente na mente do empreendedor. Mas, a montagem de um documento com a análise das principais variáveis envolvidas no futuro negócio, ordenadas segundo um modelo, ou uma ordem lógica, que é o que caracteriza um Plano de Negócios, é relativamente recente e se popularizou com o surgimento das chamadas empresas "ponto-com" ocorridas a partir da década de 90. Hoje, o "Business Plan" ou Plano de Negócios, faz parte de nosso cotidiano e quando se fala em um novo empreendimento, quase que fatalmente se fala na elaboração de um Plano de Negócios como o primeiro passo a ser dado.

Para a maioria dos empreendedores, a elaboração do Plano de Negócios tem como principal objetivo a apresentação do empreendimento a possíveis futuros parceiros comerciais como sócios, incubadoras e investidores.

Porém, embora sirva muito bem para essa finalidade, considera-se que o principal benefício da montagem de um Plano de Negócio está no conhecimento adquirido pelo próprio empreendedor durante esse processo. Desde que levada a sério, a elaboração do Plano de Negócios induz a realização do planejamento de forma organizada, forçando o empreendedor à reflexão. 
Questões como: quem é o comprador de meu produto? É possível produzilo a um custo comercialmente viável? O projeto é lucrativo? E inúmeras outras questões a serem analisadas, são determinantes para o sucesso ou fracasso do empreendimento e a busca por essas respostas tem boas chances de gerar conhecimento para o empreendedor, diminuindo incertezas e conseqüentemente os riscos para o empreendedor.

\subsection{Pousada}

Segundo SEBRAE (2005) as Pousadas são inspiradas nas hospedarias do passado, são a versão contemporânea daqueles estabelecimentos em que se pode conjugar o aconchego de um lar, à isenção de tarefas domésticas proporcionada pelos hotéis. Elas são fenômenos razoavelmente recentes, mas já estão presentes na maioria das cidades de pequeno e médio porte com vocação turística. Representam alternativa de hospedagem mais acessível, sem que isso signifique ausência de conforto ou charme. Ao contrário, charme, conforto e personalidade são os primeiros pontos em que o empreendedor da área deve investir. As Pousadas mais requisitadas têm em comum 0 respeito às tradições da hospitalidade, integradas a modernos conceitos de conforto e serviços. Tudo pelo prazer de bem receber. 


\section{PLANEJAMENTO DE UMA POUSADA}

Esta seção trata do planejamento que é necessário para empreender uma Pousada.

\subsection{Planejamento}

Para dar início a algum empreendimento é necessário primeiramente elaborar um planejamento. Planejar na visão de Batista (1981, p.13), se refere ao "processo permanente e metódico de abordagem racional e cientifica de problemas."

Ackoff (1976, p.3), argumenta que o conceito de planejamento é: "um processo que se destina a produzir um ou mais estados futuros desejados e que não deverão ocorrer a menos que alguma coisa seja feita."

Para Mewman apud Holanda (1985, p.36), "Planejar e decidir antecipadamente o que deve ser feito, ou seja, o planejamento e uma linha de visão preestabelecida.".

A definição que sintetiza melhor este trabalho é o conceito que provém de Holanda (1995, p.36):

\footnotetext{
Planejamento e a formulação sistemática de um conjunto de decisões, devidamente integrado, que expressa os propósitos de uma empresa e condiciona os meios de alcançá-los. Um planejamento consiste na definição dos objetivos, na ordenação dos recursos materiais e humanos, na determinação dos métodos e da forma de organização, no estabelecimento das medidas de tempo, quantidade espacial das atividades e em outras especificações necessárias para canalizar racionalmente a conduta de uma pessoa ou de um grupo.
}

O Turismo é feito de pequenos negócios, pois cada vez que um turista chega a uma comunidade, consome uma série de serviços que vai desde a hospedagem em uma Pousada até a refeição em um restaurante, passando pela farmácia, pelo abastecimento em um posto de gasolina etc. 
Trata-se da chamada cadeia de utilização de serviços turísticos, vale destacar que se um desses prestadores de serviços falharem no atendimento, toda a cadeia estará prejudicada, causando ma impressão acerca do destino visitado. A qualidade está diretamente vinculada às expectativas dos clientes. Isto é, se os serviços estiverem de acordo com o esperado, possuírem boa qualidade, forem além das expectativas do cliente o estabelecimento com certeza apresenta um ótimo diferencial em comparação à concorrência.

A partir deste pressuposto pode-se dizer que a qualidade de um serviço prestado por uma Pousada, deve ser vinculada às expectativas do cliente e para que isso aconteça deve-se investir cada vez mais no que se refere à mão-de-obra qualificada, através de treinamentos, reuniões cursos entre outros se a Pousada investir nessas expectativas desejadas e inesperadas, isso representará em um diferencial competitivo.

Em linhas gerais, as etapas que constituem o dia-a-dia de uma Pousada são as seguintes:

- recebimento, atendimento e alojamento dos clientes;

- arrumação e limpeza dos quartos e da área exterior;

- preparação das refeições;

- atendimento do bar e do restaurante, além do serviço de quartos;

- serviços de lavanderia (que pode ser terceirizado);

- encerramento das contas dos clientes;

- serviços de reservas.

Vale observar que um bom projeto e uma boa administração não são suficientes para fazer uma Pousada sobreviver além da estação. O negócio exige ampla pesquisa sobre a cidade, a demanda de turistas e a concorrência. $O$ desempenho desse tipo de empreendimento oscila segundo a situação econômica e a infra-estrutura da região. Além disso, mesmo em condições favoráveis, o empreendimento só terá continuidade se o empresário estiver envolvido com a área. 


\subsection{Aspectos legais para abertura do empreendimento}

Esta seção trata das providências necessárias (aspectos legais) para a abertura de uma atividade empresarial. Inicialmente é necessário ter um imóvel próprio ou alugado para poder fixar o empreendimento. No caso de imóvel alugado, para proceder ao contrato de locação, é necessário verificar o estado de conservação do imóvel. Se for necessário o imóvel poderá ser reformado adequando-o às atividades que a Pousada irá oferecer.

\section{Processo de Abertura de Empresa}

Após ter escolhido o imóvel mais adequado às necessidades é preciso constituir a empresa. O negócio poderá ter "empresário" (sem sócio), ou como "sociedade empresária". Para tanto, sugere-se o auxílio de um Contador que saberá orientar o tipo de sociedade que poderá ser feita.

Por determinação legal (Deliberação normativa n. ํ 429/02), as atividades de uma POUSADA serão exercidas somente por sociedades (pessoas jurídicas) que explore ou administre meio de hospedagem, e que tenha em seus objetivos sociais o exercício de atividade hoteleira. O tipo societário a ser adotado será o de sociedade empresaria, na forma de Sociedade Anônima ou de Sociedade Limitada, sendo esta última o tipo de sociedade mais adotada pelas sociedades empresarias. A seguir serão mostrados cinco passos necessários para proceder os tramites legais na formação de uma empresa, conforme SEBRAE (2005).

\section{PASSOS LEGAIS PARA FORMAC̣ÃO DE UMA EMPRESA}

\section{Passo - A escolha do tipo societário}

A legislação brasileira estabelece 5 (cinco) tipos de sociedade, dentre as quais a "sociedade empresária" deverá optar: 
1. Sociedade em Nome Coletivo: A constituição deste tipo de sociedade é restrita às pessoas naturais (pessoas físicas, podendo ser empresário individual ou não), não sendo admitido que outras sociedades (pessoas jurídicas) participem do quadro societário de uma sociedade em nome coletivo. No que se refere ao objeto social, este tipo societário pode explorar atividade econômica, comercial ou civil, na qual perante terceiros, os sócios respondem solidária e ilimitadamente.

2. Sociedade em Comandita Simples: É formada por duas espécies de sócios: comanditados, com responsabilidade solidária e ilimitada, e comanditários, com responsabilidade limitada;

3. Sociedade em Comandita Por Ações: Sociedade em que o capital é dividido em ações, respondendo os sócios ou acionistas, tão-somente, pelo preço das ações subscritas ou adquiridas, com responsabilidade subsidiária, solidária e ilimitada dos diretores ou gerentes pelas obrigações sociais. Tal como a sociedade por cotas de responsabilidade limitada, pode utilizar-se de firma ou denominação.;

4. Sociedade Anônima: A companhia ou sociedade anônima terá o capital dividido em ações e a responsabilidade dos sócios ou acionistas será limitada ao preço da emissão das ações subscritas ou adquiridas ;

5. Sociedade Limitada: É aquela sociedade formada por duas ou mais pessoas com um objetivo comum, assumindo todas, de maneira subsidiária, responsabilidade solidária pelo total do capital social.

\section{2ํ Passo - O Nome da Empresa}

O segundo passo é a escolha do nome da empresa. Dependendo do tipo de sociedade escolhida, o nome da empresa pode ser em forma de denominação social ou firma.

A sociedade limitada pode adotar tanto firma como denominação social, mas ao final do nome deve constar a palavra "limitada" ou sua abreviatura "Ltda.". A 
firma será composta com o nome de um ou mais sócios, desde que pessoas físicas, de modo indicativo da relação social.

A denominação deve designar o objeto da sociedade, sendo permitido nela figurar o nome de um ou mais sócios. A inscrição do nome da empresa (firma ou denominação social) no respectivo órgão de registro (Junta Comercial), assegura o seu uso exclusivo, no mesmo ramo de atividade, nos limites do respectivo Estado em que a empresa for registrada. Entretanto, caso se queira estender a proteção e o uso com exclusividade do nome (marca) da empresa para todo o território nacional, deve-se requerer o registro no Instituto Nacional de Propriedade Industrial - INPI.

Após escolhido o nome da empresa, é preciso fazer o pedido de busca na Junta Comercial e também na EMBRATUR para se verificar se não há outra sociedade registrada com o mesmo nome. Esta busca é realizada mediante o pagamento de uma taxa. É muito importante também que você faça uma pesquisa no INPI para saber se existe alguma marca registrada semelhante ao nome de sua empresa.

\section{3o Passo - Providenciar os seguintes documentos}

Neste Passo os documentos necessários são:

- Fotocópia do IPTU do imóvel onde será a sede da empresa;

- Contrato de locação registrado em cartório (se o imóvel for alugado), ou declaração do proprietário (quando o imóvel for cedido);

- Fotocópia autenticada do RG e CPF/MF dos Sócios;

- Fotocópia autenticada do comprovante de endereço dos Sócios;

- Verificar as exigências do Conselho Regional quanto à elaboração do Contrato Social, especialmente sobre formação societária e responsabilidades técnicas. 


\section{Passo - Contrato Social}

Para o registro da sociedade, é preciso elaborar e apresentar o contrato social da empresa na Junta Comercial. É válido destacar que o contrato social representa para a empresa (pessoa jurídica), o que a certidão de nascimento representa para as pessoas físicas. Neste contrato devem constar cláusulas exigidas pela legislação em vigor, que estabeleçam regras a serem observadas pelos sócios, inclusive os direitos e deveres de cada um. Recomendamos que ele seja elaborado por um advogado, entretanto, muitos Contadores possuem modelos para este fim. Ao final, o contrato deve ser assinado por um advogado, exceto se tratar de microempresa ou empresa de pequeno porte nos termos da Lei $n^{\circ}$ 9.841/99.

Deverá ser providenciada a averbação do contrato social junto ao Conselho Regional antes de registrá-lo na Junta Comercial do Estado do Estado ou Município.

Cláusulas necessárias de um contrato social:

a) Tipo societário;

b) Qualificação completa dos sócios;

c) Endereço completo da empresa;

d) Nome empresarial (firma ou denominação social);

e) Objeto social (indicação da atividade da empresa);

f) Capital social (é a quantia necessária, representada por bens ou dinheiro, necessária para que a empresa possa iniciar suas atividades);

g) Valor da quota de cada sócio no capital social;

h) Responsabilidade limitada dos sócios;

i) Forma de convocação das reuniões ou assembléias;

j) Nomeação do administrador e seus poderes (no próprio contrato social ou em documento separado);

k) A participação de cada sócio nos lucros e nas perdas; 
I) Exclusão ou falecimento de sócio;

m) Regulamentar a cessão de cotas sociais;

n) Foro de eleição (indicação do juízo em que deverá ser resolvida qualquer controvérsia referente ao contrato social);

o) Prazo de duração da empresa.

\section{Passo - Órgãos de Registro}

a. Registro na Junta Comercial. O registro da Sociedade Empresária é feito na Junta Comercial e deve seguir os seguintes passos: Após escolher o nome da empresa, realizar a busca do nome e providenciar a documentação mencionada, você deverá confeccionar 4 (quatro) vias de igual teor do contrato social, com todas as folhas rubricadas e a última assinada pelos sócios, testemunhas e advogado (micro ou pequena empresa está dispensada da assinatura de advogado). Em seguida, o contrato social deverá ser entregue na Junta Comercial, juntamente com os demais documentos exigidos pelo órgão.

b. Receita Federal (Cadastro Nacional da Pessoa Jurídica - CNPJ). Todas as pessoas jurídicas, inclusive as equiparadas (empresário e pessoa física equiparada à pessoa jurídica), estão obrigadas a se inscrever na Receita Federal.

c. Secretaria da Fazenda do Estado ou Município. Caso a POUSADA, além de prestar os serviços de hospedagem, também venha fornecer refrigerantes, alimentos, serviços de transporte, faz com que ela seja contribuinte do ICMS e, conseqüentemente, está obrigada a se registrar na Secretaria da Fazenda do Estado ou Município que para este registro será necessário que indique o número do $\mathrm{CRC}$ (registro no Conselho Regional de Contabilidade) do Contador responsável.

O registro na Secretaria da Fazenda para obtenção da Inscrição Estadual (IE), destinada aos contribuintes do ICMS, deve ser feito junto ao Posto Fiscal 
Eletrônico da Secretaria da Fazenda do Estado ou Município, pela internet, no seguinte endereço www.pfe.fazenda.sp.gov.br

d. Inscrição na Prefeitura Municipal. Estão sujeitas à inscrição no Cadastro de Contribuintes Mobiliários (CCM) do Município de São Paulo, as pessoas físicas e jurídicas estabelecidas no Município que desenvolvam algum tipo de atividade.

e. Registro na Embratur. É necessário que a Pousada seja registrada na EMBRATUR, obtendo-se assim a devida autorização de funcionamento, conforme os termos do Decreto ํo 84.910/80. Somente poderão explorar ou administrar Meios de Hospedagem de Turismo, Restaurantes de Turismo e Acampamentos Turísticos no país, empresas ou entidades registradas na Empresa Brasileira de Turismo - EMBRATUR.

O registro das empresas ou entidades de que trata este Decreto está condicionado à comprovação do atendimento dos seguintes requisitos:

I - habilitação legal para funcionar, concedida pelos órgãos competentes;

II - condições técnico-operacionais, decorrentes da existência de recursos humanos e materiais adequados aos serviços a serem prestados;

III - idoneidade financeira, comprovada pela realização do capital adequado e referências bancárias.

Os requisitos para cadastramento podem ser consultados no site: www.embratur.gov.br.

\subsection{A Informação no Funcionamento da Pousada}

O produto turístico, por suas características de intangibilidade, por não ser inspecionado antes da compra, por sua complexidade e enorme interdependência, representa um desafio para os fornecedores. O fornecimento de informação precisa e atual é relevante e essencial para operação eficiente da indústria do Turismo. (Cooper et al; 1998).

Segundo O`Connor, (2001), o intercâmbio de informações é muito importante em cada estágio do ciclo de vendas do produto turístico (nesse caso 
hospedagem). A informação deve fluir rápida e precisa entre o cliente, os intermediários e cada uma das empresas de Turismo envolvidas no atendimento das necessidades do cliente.

Conforme Ives \& Learmonth (1990), a Tecnologia de Informação (TI) pode fornecer ferramentas e infra-estrutura que possibilitem uma empresa servir seus clientes por todo o ciclo de vida do atendimento. Apontam o ciclo de vida do atendimento ao cliente como ferramentas obrigatórias para gerenciar a força do cliente por intermédio de estratégias de diferenciação.

Se o fornecedor pode auxiliar o cliente durante todo o ciclo de vida, este pode ser capaz de se diferenciar dos seus competidores normalmente por meio de uma melhoria no atendimento ao cliente ou em alguns casos, gerando redução dos custos diretos. (Ives \& Learmonth, 1990; 1197).

Conforme (Poon, 1993). A importância da tecnologia é crucial para a consecução do êxito empresarial. Hoje é de domínio dos empresários que a questão não é quando a Tecnologia da Informação terá um impacto na posição competitiva da empresa, mas sim quando e como esse impacto ocorrerá.

Desenvolvimento em Tecnologias da Informação e da Comunicação - TIC têm revolucionado tanto a economia quanto os empreendimentos. Tecnologia da Informação é definida segundo (Poon, 1993). O termo coletivo para os mais recentes desenvolvimentos no formato eletrônico, de mecanismos computadorizados e tecnologias da comunicação utilizadas para aquisição, processamento, análise, armazenamento, consultas, disseminação é a aplicação da informação.

Segundo (Buhalis, 1998). A TI na esfera da microeconômica permeia todas as funções de gerenciamento estratégico e operacional, incrementando a competitividade das empresas.

Frew e Pringle (1995) identificam uma relação entre o tamanho e a tendência de utilizar sistemas de computadores, com as pequenas e médias empresas também têm recursos limitados, não apenas em termos financeiros, mas também de gerenciamento e de tempo de funcionários, e o uso de canais eletrônicos é considerado complicado e difícil.

Segundo (Eerthner, 2003) O avanço do Turismo pela internet tem alterado profundamente a hierarquia da direção da informação e dos pagamentos. Com a 
modalidade do comercio eletrônico um turista pode fazer sua reservas pela rede, de qualquer combinação de serviços de Turismo, com ou por meio de qualquer combinação de fornecedores ou intermediários.

Embora não haja uma definição única do que seja Turismo, as Recomendações da OMT sobre Estatísticas de Turismo, o definem como "as atividades que as pessoas realizam durante suas viagens e permanência em lugares distintos dos que vivem, por um período de tempo inferior a um ano consecutivo, com fins de lazer, negócios e outros." "Segundo a Organização Mundial de Turismo, a atividade movimenta mais de US\$ 3,5 trilhões anualmente ${ }^{1}$, bem como é considerado por vários órgãos de pesquisa como um dos ramos de atividade que mais cresce no mundo". O Turismo é uma atividade que vem crescendo e se desenvolvendo no Brasil e no mundo. A estimativa de geração de novos empregos é grande devido ao aumento de demanda, porém o profissional que o mercado busca um profissional preparado para a função, que tenha conhecimento de dois idiomas e no mínimo curso superior.

No Brasil, atualmente, os empresários do setor vêem explorando os novos nichos do mercado. Apesar da crescente oferta de vagas nos mais diversos cargos de redes hoteleiras, os empregadores têm sentido a carência de mão-de-obra qualificada, pois em geral a escolaridade das pessoas disponíveis para funções operacionais é baixa. Como agravante, há ainda a carência de profissionais multifuncionais no mercado. Durante muito tempo houve um certo menosprezo por esse tipo de formação profissional. À época se repetia, que essas habilidades não se aprendiam na escola. Passados alguns anos, a hotelaria e o Turismo surgem como "estrelas" nas escolas superiores. Houve uma época em que expressões como sociedade pós-industrial, setor terciário e formação profissional para o mercado eram desconhecidas ou menosprezadas, sendo hoje mais valorizadas.

Em seu início, a informática era tida como um mecanismo que tornava possível automatizar determinadas tarefas em grandes empresas e nos meios governamentais. Com o avanço tecnológico, as "máquinas gigantes" começaram a perder espaço para equipamentos cada vez menores e mais poderosos. A evolução das telecomunicações permitiu que, aos poucos, os computadores passassem a se

\footnotetext{
${ }^{1}$ EcoTurismo: instrumento do desenvolvimento. Disponível em: http://www.Aultimaarcadenoe.com /instru.htm. Acesso em 10 de jun. 2007
} 
comunicar. Como conseqüência, esses equipamentos deixaram de simplesmente automatizar tarefas e passaram a lidar com Informação.

A informação é um insumo fundamental nas organizações. Conceitualmente é um conjunto de dados classificados e organizados de forma que um usuário ou uma empresa possa utilizá-la a seu favor. A informação é, inclusive, um fator que pode determinar a sobrevivência ou a descontinuidade das atividades de uma empresa. Isso não é difícil de ser entendido, basta imaginar o que aconteceria se uma instituição financeira perdesse todas as informações relativas aos seus clientes.

Apesar de possível, muito dificilmente uma empresa de grande porte pode perder suas informações, principalmente quando se fala de bancos, casas de câmbio, entre outros. No entanto, o que ocorre com mais freqüência é o uso inadequado das informações adquiridas ou, ainda, a subutilização destas.

A Tecnologia da Informação (TI) pode ser definida como um conjunto de todas as atividades e soluções providas por recursos de computação. Na verdade, as aplicações para $\mathrm{TI}$ são tantas e estão ligadas às mais diversas áreas, que existem várias definições e nenhuma consegue determiná-la por completo. 


\section{ESTUDO DE CASO: POUSADA EM ALTO PARAÍSO}

A principal atividade de uma Pousada é a hospedagem propriamente dita, cuja qualidade do serviço é de fundamental importância para o sucesso da empresa. Este setor deve ser cuidadosamente organizado para assumir o papel de um ambiente familiar para o hóspede. Vale observar que o nível elevado de qualidade poderá aumentar os custos, no entanto, é importante que o mesmo seja controlado e a qualidade seja mantida.

Uma empresa hoteleira pode ser entendida como sendo uma organização que, mediante o pagamento de diárias, oferece alojamento à clientela. Empresa hoteleira, segundo a Embratur (Instituto Brasileiro de Turismo), é a entidade jurídica que explora ou administra os meios de hospedagem e que tem em seus objetivos sociais o exercício da atividade hoteleira (Castelli, 1999). As empresas hoteleiras podem ser classificadas, quanto ao seu tamanho, em pequenas, médias e grandes. O parâmetro que fundamenta essa classificação pode ser o apartamento (unidade habitacional), o número de leitos ou a receita anual. No caso do Brasil, a classificação, segundo o Conselho Nacional do Turismo, é feita a partir da receita anual, mantendo os padrões segundo os 'valores de referência'.

Como mencionado anteriormente, visando uma melhor elaboração do empreendimento objeto deste estudo foram realizadas entrevista em quatro hotéis de Alto Paraíso - GO. Eles foram escolhidos aleatoriamente, levando-se em consideração os seguintes critérios: um de pequeno porte, dois de médio porte e outro de grande porte.

O objetivo foi coletar dados mais concretos. A pesquisa foi realizada utilizando questões abertas e fechadas junto aos gerentes ou proprietários de forma que eles pudessem expressar suas idéias mais claramente, não se atendo somente às respostas pré-estabelecidas. As entrevistas foram realizadas no período de 24/01/2007 a 26/01/2007, cujo resultado será apresentado a seguir. 


\subsection{Análise dos Resultados}

Como pode ser visto na Tabela 4.1 as empresas pesquisadas já estão estabelecidas há bastante tempo na cidade, variando de 5 a 20 anos de existência. Todas elas têm mais de 7 apartamentos no seu estabelecimento, sendo portanto, caracterizadas como de pequeno porte.

Tabela 4.1

Características das Empresas Entrevistadas

\begin{tabular}{c|c|c|c|l}
\hline \multicolumn{1}{c|}{ Nome } & Inauguração & apartamentos & Padrão & Entrevistado \\
\hline Hotel Nunes & 1987 & 10 & Econômico & Proprietário \\
\hline Hotel Europa & 1991 & 17 & Econômico & Proprietário \\
\hline Alfa \& Ômega & 1992 & 12 & Econômico & Gerente \\
\hline $\begin{array}{l}\text { Pousada } \\
\text { Bambu Brasil }\end{array}$ & 2002 & 7 & Rústico com & Proprietário \\
conforto & \\
\hline
\end{tabular}

Verificou-se através da pesquisa que o público alvo das Pousadas são em sua maioria de idosos, havendo também com freqüência casais em lua de mel. $O$ fluxo de hóspedes é relativamente estável durante o ano, diminuindo em baixa temporada e aumentando em alta temporada.

Quanto ao preço da hospedagem, este varia, pois há Pousadas de pequeno, médio e grande porte. Considerando os finais de semana, feriados, alta estação e baixa estação, também há uma variação nos preços, ficando em média entre os valores de $R \$ 30,00$ a $R \$ 80,00$ no hotel de pequeno porte; $R \$ 50,00$ a $\mathrm{R} \$ 100,00$ no hotel de médio porte e $\mathrm{R} \$ 80,00$ a $\mathrm{R} \$ 148,00$ no hotel de grande porte. Observou-se ainda que $75 \%$ dos hotéis não utilizam promoções, sendo que somente uma empresa, (25\%) faz a promoção a partir de 3 (três) diárias, sendo este considerado um atrativo.

Quanto ao faturamento mensal das empresas há variação dependendo, se está na temporada ou fora de temporada varia da seguinte forma: 
- Grande porte varia de $\mathrm{R} \$ 10.000,00$ a $\mathrm{R} \$ 40.000,00$;

- Médio porte varia de $\mathrm{R} \$ 3.000,00$ a $\mathrm{R} \$ 6000,00$;

- Pequeno porte varia de $\mathrm{R} \$ 1.000,00$ a $\mathrm{R} \$ 3.000,00$

As despesas mensais das Pousadas de grande porte variam de $R \$ 3.500,00$ com pessoal e $R \$ 7.000,00$ com manutenção, perfazendo um total de $R \$ 10.000,00$. O lucro bruto da Pousada de grande porte é de $R \$ 40.000,00$ menos as despesas $R \$ 10.000,00$ ficando um lucro líquido em torno de $R \$ 20.000,00$, pois ainda há as despesas com impostos dentre outros.

O retorno do investimento se dá de 3 a 6 anos. Quanto aos móveis e utensílios observou-se que nenhuma das Pousadas lá instaladas possuem ar condicionado, $100 \%$ possuem ventilador, $75 \%$ possuem freezer, $25 \%$ possuem cofre, $75 \%$ possuem televisão, $50 \%$ possuem piscinas, $75 \%$ possuem estacionamentos. Quanto ao grau de satisfação financeira com seu empreendimento, verificou-se que $50 \%$ está satisfeito e que $75 \%$ não investiria em outro empreendimento.

A Tabela 4.2 apresentada a seguir mostra os principais concorrentes dos Hotéis entrevistados e os seus respectivos pontos fortes e fracos, vale observar que elas são resultantes das entrevistas realizadas.

Tabela 4.2

Pontos Fortes e Fracos dos Hotéis

\begin{tabular}{|c|c|c|c|c|}
\hline Hotéis & Concorrentes & Diferencial & Pontos Fortes & Pontos Fracos \\
\hline Nunes & Nenhum & $\begin{array}{l}\text { - Clientes são } \\
\text { indicados por } \\
\text { outros } \\
\text { clientes } \\
\text { hospedados } \\
\text { anteriormente }\end{array}$ & $\begin{array}{c}\text { Localização } \\
\text { e } \\
\text { Preço }\end{array}$ & $\begin{array}{l}\text { Necessidade de } \\
\text { reforma }\end{array}$ \\
\hline Europa & Nenhum & $\begin{array}{l}\text { - Guias são } \\
\text { selecionados } \\
\text { - Há suporte para } \\
\text { passeios }\end{array}$ & $\begin{array}{l}\text { Atendimento } \\
\text { Café da } \\
\text { manhã colonial } \\
\text { Localização } \\
\text { privilegiada }\end{array}$ & $\begin{array}{l}\text { Necessidade de } \\
\text { reforma }\end{array}$ \\
\hline $\begin{array}{l}\text { Alfa } \\
\text { e } \\
\text { ômega }\end{array}$ & $\begin{array}{ll}\text { Pousada } & \text { Casa } \\
\text { Rosa } & \\
\text { Pousada } & \\
\text { Camelot } & \\
\text { Pousada } & \\
\text { Recanto } & \text { da }\end{array}$ & $\begin{array}{l}\text { - Lavanderia } \\
\text { - Guias } \\
\text { especializados } \\
\text { - Transfer }\end{array}$ & $\begin{array}{l}\text { Atendimento } \\
\text { Localização } \\
\text { Muito tempo } \\
\text { no mercado da } \\
\text { Café } \\
\text { manhã }\end{array}$ & $\begin{array}{l}\text { Estacionamento } \\
\text { coberto }\end{array}$ \\
\hline
\end{tabular}




\begin{tabular}{l|l|l|l|l}
\hline & grande paz & & & \\
\hline Bambu & Casa das Flores & $\bullet$ Cafeteria & Arquitetura & $\bullet$ Ampliações \\
Brasil & Cristal da Terra & $\bullet$ Restaurante & Conforto & de \\
& Mundo da Lua & $\bullet$ Guias & Instalações & equipamentos \\
& & Turísticos & Decoração & $\bullet$ Sauna \\
& & Atendimento & $\bullet$ Ofurô \\
& & Leitura \\
& & Tarô de & & \\
\hline
\end{tabular}

Pela pesquisa de campo realizada, o Hotel Nunes informou que não há concorrentes (tabela 4.2) para ele. Declarou ainda que se considera absoluto, pois os clientes que lá se hospedam sempre retornam, havendo portanto fidelização de clientes.

O ponto forte do Hotel Nunes é o preço e este se encontra bem localizado, porém como ponto fraco foi apontado que precisa de uma reforma, as instalações estão antigas e precisa de pintura.

O Hotel Europa também se considera absoluto, sendo o que o diferencia dos demais hotéis é a existência de guias selecionados e suporte para passeio.

O ponto forte do Hotel Europa está no atendimento. Ele oferece café da manhã colonial e possui uma ótima localização. Quanto ao Ponto Fraco observou-se a necessidade de reforma interna.

O Hotel Alfa e Ômega possui vários concorrentes, isto ocorre por serem eles de pequeno porte, possuirem os mesmos utensílios e serem do mesmo estilo, diferenciando-se apenas no preço e no diferencial tais como: lavanderia, guias especializados e transfer.

Os Pontos Fortes são o atendimento, a localização, o tempo de mercado e o excelente café da manhã que é oferecido. O problema principal, ou seja, o ponto fraco é não possuir estacionamento coberto.

Do mesmo modo que o Hotel Alfa e Ômega, o hotel Bambu Brasil possui vários concorrentes, conforme visto na Tabela 4.2. No entanto, por serem hotéis de médio porte, possuem os mesmos utensílios e são do mesmo estilo, diferenciandose apenas no preço e nos diferenciais principais que são cafeteria, restaurantes, guias turísticos Massagem e leitura de tarô. 
Do ponto de vista dos Pontos Fortes e Fracos, a Pousada Bambu Brasil apresenta como pontos fortes a arquitetura, o conforto, as instalações, a decoração e $\mathrm{o}$ atendimento. Os Pontos Fracos estão na ampliação de equipamentos, sauna e ofurô.

Quanto ao grau de satisfação dos clientes, (gráfico 4.1), observou-se que $25 \%$ considera excelente, $50 \%$ considera ótimo e o restante com $25 \%$ considera bom. Observou-se também que o os clientes em geral, estão satisfeitos com os hotéis.

Gráfico 4.1 - Grau de Satisfação dos clientes

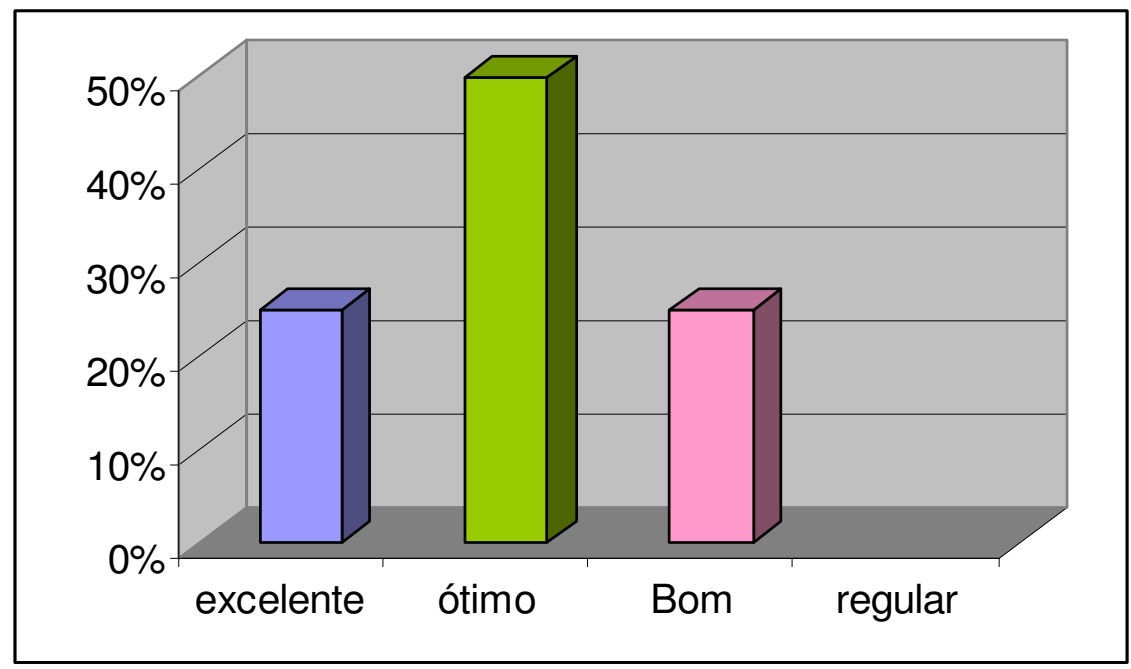

Quanto ao grau de fidelidade dos clientes (gráfico 4.2), ficou demonstrado que $70 \%$ dos clientes sempre retornam $10 \%$ não retornam e o restante, ou seja, $20 \%$ retornam ocasionalmente. Pela entrevista, observou-se que os clientes retornam, pois gostam do hotel e do lugar que é muito atrativo.

Gráfico 4.2 - Grau de fidelidade dos clientes

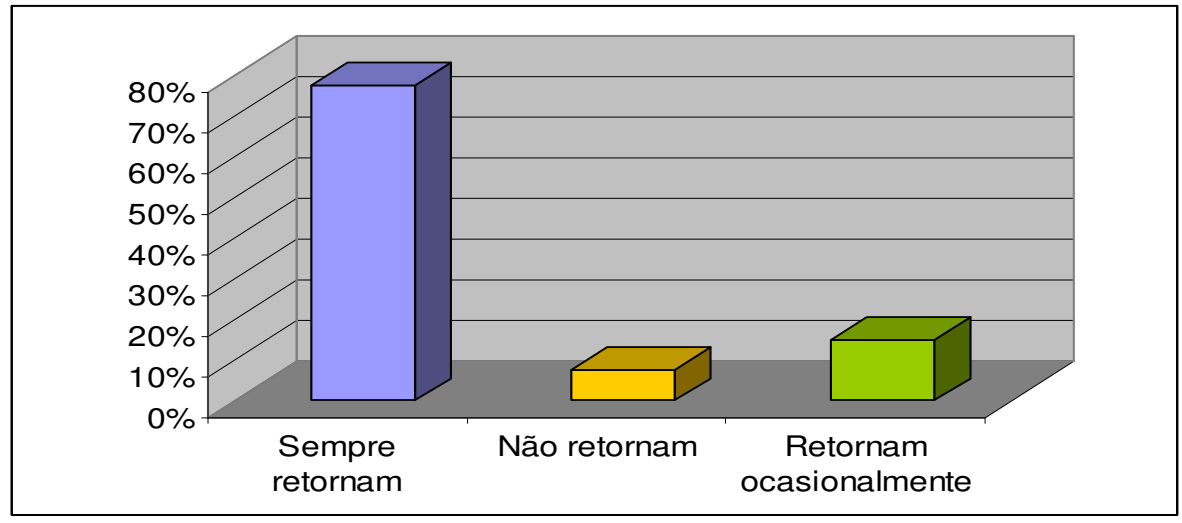


Quanto à reação dos concorrentes frente à instalação de mais uma Pousada na cidade (gráfico 4.3), dos entrevistados $75 \%$ age com indiferença e $25 \%$ apóia a entrada da concorrência. Observou-se, que a indiferença se dá devido ao alto grau de segurança que cada um tem em relação ao seu empreendimento.

Gráfico 4.3 - Reação dos concorrentes frente à entrada de mais uma Pousada

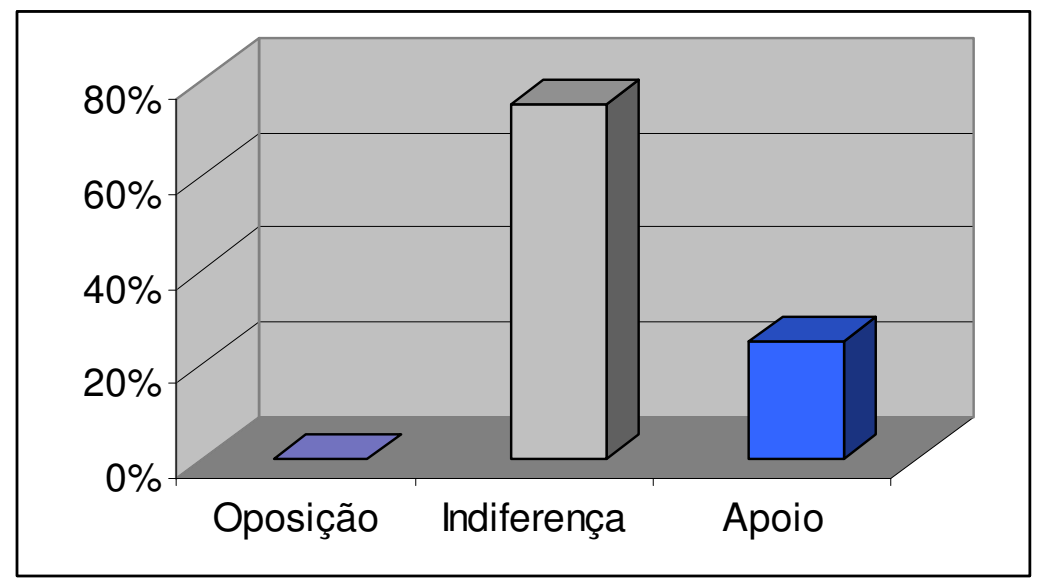

Quanto ao estágio do mercado turístico de Alto Paraíso, (gráfico 4.4), 50\% dos entrevistados consideram que está crescendo, 25\% acham que está em declínio e os outros $25 \%$ consideram estar em estagnação. O crescimento foi o destaque porque empresas estrangeiras estão investindo cada vez mais no local, o que representa uma concorrência relevante.

Gráfico 4.4 - O mercado turístico de Alto Paraíso se encontra em qual estágio

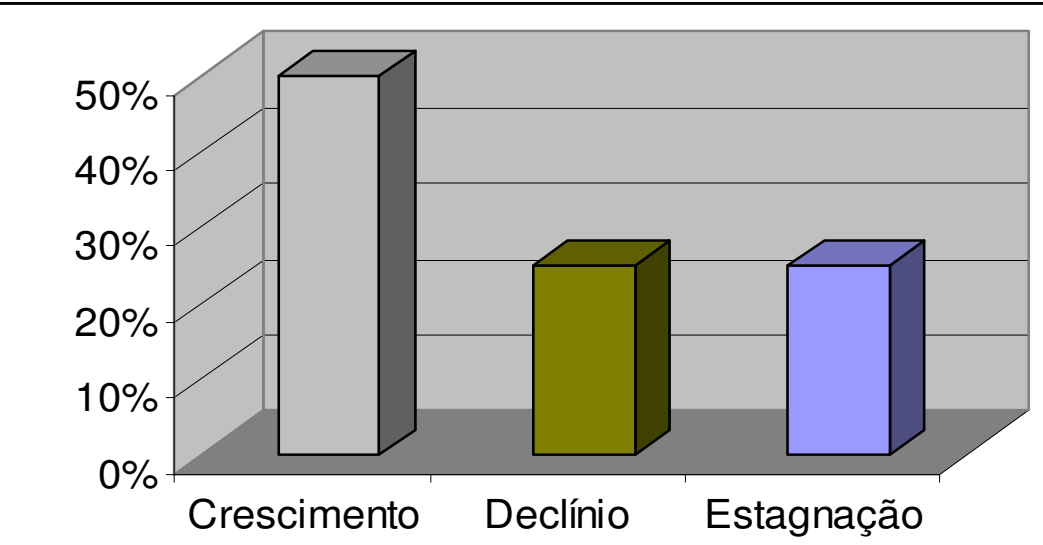


Quanto à classificação da Pousada, (gráfico 4.5), 50\% dos entrevistados consideram ótimo, $25 \%$ consideram bom e os outros $25 \%$ consideram regular. $O$ destaque se deu nos que consideram ótimo porque há segurança no empreendimento e os clientes são fidelizados.

Gráfico 4.5 - Como classifica a sua Pousada

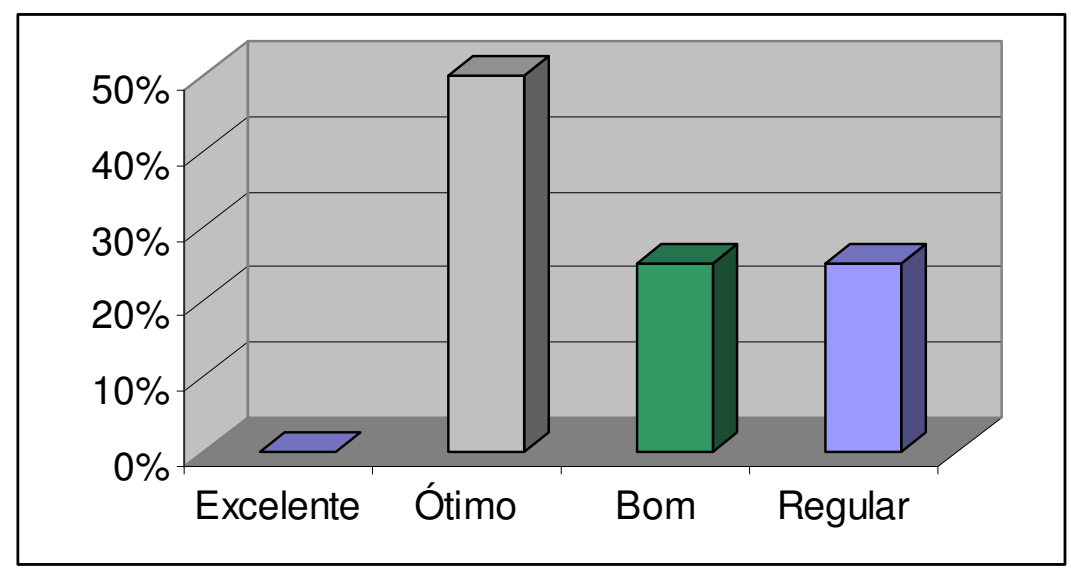

Quanto aos principais canais de distribuição, (gráfico 4.6), a pesquisa revelou que $50 \%$ utilizam internet, $25 \%$ faz divulgação por meio de revistas e o restante, $25 \%$ é por indicação de outros clientes.

Gráfico 4.6 - Principais canais de distribuição

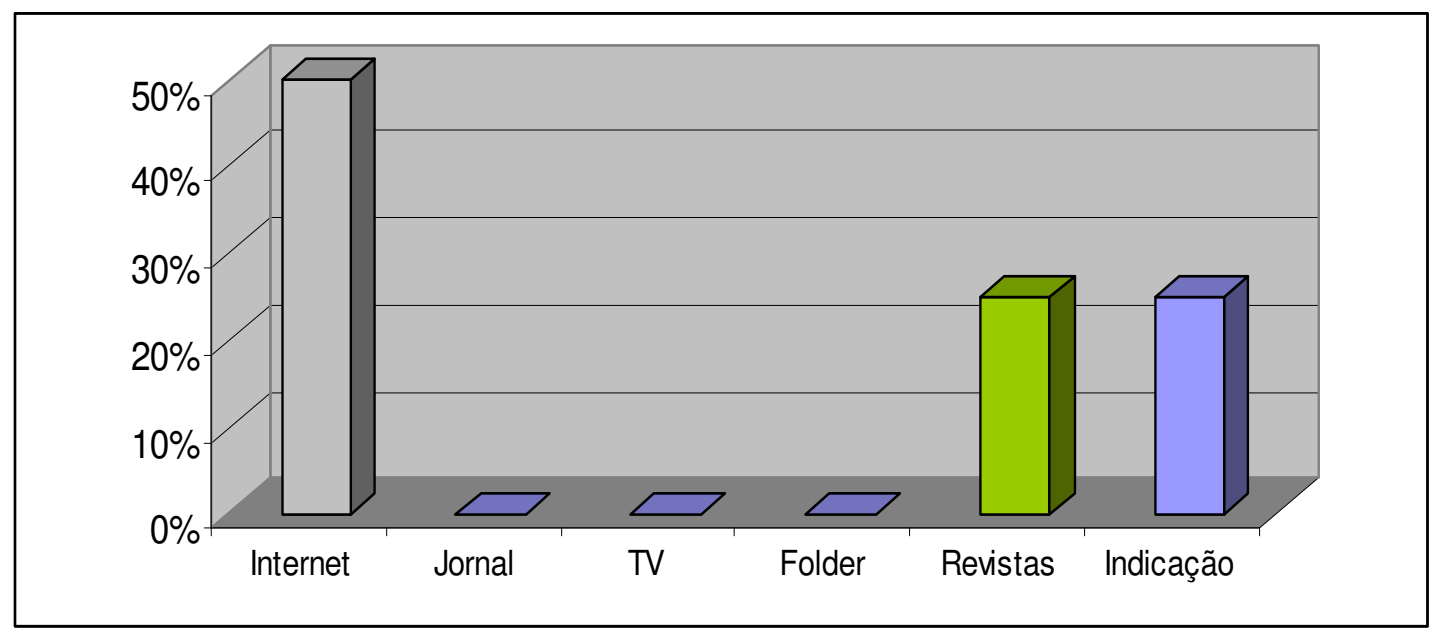

Por ser a internet um meio de comunicação bem aceito, este vem sendo o canal mais utilizado pelos hotéis. 


\section{PLANO DE NEGÓCIO DA POUSADA PROPOSTA}

Esta seção visa apresentar o conceito de Plano de Negócio como também os elementos necessários ao seu desenvolvimento, tais como: produto, mercado, Marketing e recursos.

Plano de Negócios pode ser definido como um instrumento de planejamento que levanta uma série de questões que deverão ser respondidas pelo empreendedor de forma a prepará-lo para a montagem efetiva do negócio ou um projeto que formule e viabilize um formato mais adequado do empreendimento. O quadro a seguir mostra a estrutura de um modelo de Plano de Negócios elaborado segundo esse conceito.

\section{ESTRUTURA DE UM PLANO DE NEGÓCIO}

\begin{tabular}{lll}
\hline \multicolumn{1}{c}{ Questões para o empreendedor } & \multicolumn{1}{c}{ Módulo } \\
\hline O QUE vai ser feito? POR QUEM vai ser feito? & 1. O EMPREENDIMENTO \\
\hline O QUE vai ser oferecido ao mercado? & 2. O PRODUTO \\
\hline A QUEM vai ser oferecido e QUEM vai competir conosco? & 3. O MERCADO \\
\hline COMO o cliente vai ser atendido? & 4. MARKETING \\
\hline QUANTO gastará e QUANTOS terão de retorno? & 5. FINANÇAS \\
\hline QUANDO realizaremos as atividades e atingiremos as metas? & 6. CRONOGRAMA DE \\
\hline
\end{tabular}

De uma forma sintética, esse quadro apresenta praticamente quase todos os aspectos relevantes para o desenvolvimento de um empreendimento. Um empreendedor que seja capaz de planejar e responder satisfatoriamente a essas questões, com certeza estará melhor preparado para enfrentar o mercado. 
Evidentemente, a montagem de um bom Plano de Negócios não garante o sucesso do empreendimento, mas, sem dúvida, representa um importante passo nessa direção.

\subsection{O Empreendimento}

Manter um empreendimento envolve TEMPO e DEDICAÇÃO PLENA ao negócio. O empreendedor deve apresentar as seguintes habilidades:

$\checkmark$ Habilidade para gerenciar o empreendimento - conhecer sobre gerência de projetos

$\checkmark$ Capacidade de encontrar oportunidades e gerar negócios bem sucedidos e

$\checkmark$ Capacidade de mobilizar recursos para sustentar o negócio (atendimento ao cliente, manutenção do estabelecimento, espaço físico, luz, água, telefone, fax, advogado, contador, etc).

Segundo a Fundação para o Premio Nacional da Qualidade, a estratégia é o caminho para posicionar a organização de forma competitiva e garantir sua sobrevivência em longo prazo no mercado. As estratégias podem conduzir a novos produtos, novos mercados, crescimentos de receitas, redução dos custos, aquisições, fusões e novas alianças e parcerias.

Para Enesto (2004, p. 211):

O negócio hoteleiro representa a exploração comercial do imóvel mediante o aluguel de quartos, o serviço de Governanta, a venda de alimentos e bebida, o espaço para eventos, dentre outras formas de obtenção de receita que, para efeito de cálculo de resultado devem deduzir todas as despesas operacionais.

Cândido (2001, p. 46) faz a seguinte afirmação acerca da qualidade em serviços:

A qualidade em serviços está determinando o sucesso e em alguns casos a sobrevivência de empresas hoteleiras no mercado brasileiro. Diante da concorrência acirrada, os empreendedores com essa meta têm o foco nas necessidades e expectativas dos clientes. 
Por esse motivo ressalta-se que sem qualidade não há empreendimento que sobreviva. As Pousadas estão entre os empreendimentos que mais sofrem os efeitos da sazonalidade. As Pousadas das regiões de montanhas e cachoeira não é muito diferente, tendo seu período de maior ocupação em temporada de inverno.

O empreendimento proposto por este estudo será a construção de uma Pousada de médio porte, estabelecida em um imóvel de propriedade de dois sócios. Por serem proprietários do imóvel este fato acarretará redução de despesa com locação e entrará como bem na integralização do capital social da empresa. Vale destacar que será feita uma adaptação no imóvel para atender melhor a clientela. A Pousada contará com 20 quartos inicialmente. Os quartos deverão contar com os seguintes acessórios: Ar condicionado, Ventilador, Freezer, Televisão com TV a cabo, Piscina e Estacionamento coberto.

Quanto ao tamanho do empreendimento, a Pousada deverá ser de médio porte, uma vez que foi verificado pela pesquisa, que uma pousada de pequeno porte não seria viável. Por outro lado, uma de grande porte, para quem está iniciando no segmento seria um risco.

\subsection{Os Produtos}

Produto é algo que pode ser oferecido em um mercado para satisfazer a um desejo ou necessidade. Contudo é muito mais do que apenas um objeto físico. É o pacote completo de benefícios ou satisfação que os compradores percebem que obterão se o adquirirem. É a soma de todos os atributos físicos, psicológicos, simbólicos e de serviço.

Segundo KOTLER (1998) "produto é qualquer coisa que possa ser oferecida a um mercado para atenção, aquisição, uso ou consumo, e que possa satisfazer a um desejo ou necessidade."

Em geral, os estilos adotados pelas Pousadas vão dos mais exóticos aos mais adequados, passando pelas Pousadas mais sofisticadas, pelas que fazem tudo para agradar o Turista (adepto do Turismo com adrenalina) e até aquelas que não 
oferecem luz elétrica. O interessante é que há turista que adora esse tipo de Pousada.

Estilos à parte, o importante é não esquecer do charme - esse conceito subjetivo que significa genericamente uma união entre bom gosto, atenção com detalhes, paixão em servir, conforto compatível com expectativas dos hóspedes, localização privilegiada, construção adequada ao meio ambiente e à região, enfim, o conjunto de fatores que emprestam personalidade única ao local e ao próprio hotel.

O produto é a parte mais importante do empreendimento, pois condicionará todos os outros itens. Os serviços atenderão às necessidades da clientela ou empresas.

Como a presente pesquisa foi realizada com os futuros concorrentes do empreendimento proposto, verificou-se quais as expectativas e necessidades da clientela e o que eles gostariam que tivesse na Pousada.

Em termos de serviços, foram identificados alguns itens que poderão servir de diferencial competitivo da Pousada. Serão criados pacotes dentro e fora de temporada. Nestes pacotes estarão incluídas promoções que beneficiarão o hóspede, pois cada vez que se hospedarem na Pousada ganharão um ponto de fidelização, quanto atingirem um total de 3 estadias ao semestre ganharão um bônus dando $20 \%$ de desconto na $4^{\text {a }}$ estadia. Além disso serão oferecidos à clientela os seguintes serviços:

- Suporte para passeio, contando com guias turísticos (terceirizados);

- Leitura de Tarô;

- Serviço de lavanderia (opcional);

- Massagem;

- Sauna coletiva;

- Sala de jogos;

- Piscina coletiva;

- Ofurô;

- Café da Manhã colonial 
É importante destacar que para viabilizar esses serviços está sendo estudada uma parceria com a Bancorbrás e com a BBtur.

\subsection{O Mercado}

Segundo o SEBRAE (2005), até alguns anos atrás, hospedagem com conforto, requinte e boa comida eram exclusividade de cidade grande no Brasil. Quem quisesse viajar para o interior tinha de se contentar com "Pousadinhas" modestas, de acomodações simples e comida regional sem grande inspiração.

Os novos meios de hospedagem que hoje oferecem bem mais que isso, seguem uma tendência internacional. Em alguns países do exterior, é possível encontrar acomodações mágicas que, em meio a paisagens estonteantes, oferecem serviço, conforto e comida que nada ficam a dever aos melhores hotéis cinco estrelas. No Brasil, o crescimento do Turismo rural abriu novas oportunidades de negócio em cidades de pequeno porte e as Pousadas que souberem explorar a oportunidade terão boas chances de sucesso.

Neste sentido, a localização é muito importante porque os clientes procuram lugares bonitos, arborizados, perto de rios, lagos ou do mar, cachoeiras, além de silêncio, calma, paz e aconchego. A facilidade de acesso e infra-estrutura da região também são aspectos que devem ser levados em consideração por parte do empreendedor.

O público alvo do empreendimento em pauta será composto por: idosos, casais, famílias e jovens. Conforme a pesquisa o mercado está em crescimento, portanto, uma nova empresa no mercado será indiferente. O mercado é competitivo, pois algumas Pousadas já estão estabelecidas na cidade de Alto Paraíso desde 1991, ou seja, já possuem 16 anos.

As maiores concorrentes para a Pousada proposta neste estudo são as Pousadas de médio porte, que se encontram no mesmo patamar desta, dentre elas pode-se citar:

$>$ Pousada Casa Rosa;

> Pousada Camelot; 
$>$ Pousada Recanto da Grande Paz e

$>$ Alfa \& Ômega.

Vale destacar que em todas as Pousadas foram verificadas a necessidade de reforma e muitas deixam a desejar. A clientela na maioria das vezes procura por novidades e uma boa instalação e isso faz a diferença.

\subsection{O Marketing}

"Marketing é satisfazer as necessidades e desejos do cliente" Kotler (1998).

O Marketing atua em um ambiente dinâmico e mutável, com as freqüentes alterações de valores, novas tendências, declínio ambiental, aumento da concorrência global e uma série de outros problemas políticos e sociais, que afetam as organizações e oferecem simultaneamente oportunidades de Marketing. Para tanto, as organizações precisam estar preparadas, em contínua atualização das informações e buscando corresponder às expectativas dos consumidores.

Segundo Kotler (1998) "Marketing é o processo social e gerencial através do qual indivíduos e grupos obtêm aquilo que desejam e de que necessitam, criando e trocando produtos e valores uns com os outros".

Marketing significa trabalhar com mercados, os quais, por sua vez, significam a tentativa de realizar as trocas em potencial com o objetivo de satisfazer às necessidades e os desejos humanos. Assim, o Marketing pode ser definido como uma atividade humana dirigida para a satisfação das necessidades e desejos, através dos processos de troca.

Segundo KOTLER (1998, p.30) há diversas definições de Marketing que apareceram através dos tempos:

Tem sido descrito por uma ou outra pessoa como uma atividade de negócios; como um fenômeno de comércio; como um estado de espírito; como uma função coordenadora, integradora, na definição de políticas; como um senso de propósitos dos negócios; como um processo econômico; como um processo econômico; como uma estrutura das instituições; como processo de troca ou transferência da propriedade de produtos; como um processo de concentração, equalização e dispersão; 
como a criação de tempo, lugar e posse de coisas úteis; como um processo de ajustamento da demanda e da oferta, e muitas outras coisas.

Conforme MANO2 "O Marketing participa da fixação dos padrões de vida em sociedade. Só desenvolver um bom produto não resulta, necessariamente, em sucesso empresarial, pois o produto tem que ser vendido."

Conceitua-se Marketing como uma orientação da administração baseado no entendimento de que a tarefa primordial da organização é determinar as necessidades, desejos e valores de um mercado visado e adaptar a organização para promover as satisfações desejadas de forma mais efetiva e eficiente que seus concorrentes. As premissas subjacentes ao conceito de Marketing, segundo KOTLER (1998, p.42) são:

1. A organização concebe suas missões em termos de satisfazer a um conjunto de desejos definidos de um grupo de clientes específicos.

2. A organização reconhece que a satisfação de desejos requer um ativo programa de pesquisa de Marketing para conhecer esses desejos.

3. A organização reconhece que todas as atividades de influenciar clientes devem ser colocadas sob um controle integrado de Marketing.

4. A organização acredita que ao fazer um bom trabalho em satisfazer aos clientes, ela ganha sua lealdade, repetição de negócios e palavras de recomendação, coisas que são cruciais na satisfação dos objetivos da organização.

Todas estas definições fornecem perspectivas úteis, porém apenas parciais da natureza do Marketing. Outra definição de Marketing, enraizada na lógica da natureza e do comportamento humanos é: Marketing é a atividade humana dirigida para a satisfação das necessidades e desejos, através do processo de troca.

O Marketing é, sem dúvida, uma ferramenta útil, pois consiste em um processo gerencial que envolve análise de cenários, identificação de públicos,

\footnotetext{
${ }^{2}$ MANO, Cristiane. Cadê o plano? in Aponte o Rumo de Seu Negócio. Revista Exame Digital. Ano 34n¹9-Edição 722-2000.
} 
pesquisa de necessidades e expectativas, formatação de serviços, construção de imagem e oferta de valor e estratégias de comunicação.

Pode-se denominar Marketing Empresarial às ações de Marketing praticadas no Mercado Matéria, no qual a atividade econômica predomina, através das trocas de bens por moeda. Na base das transações aí realizadas está a manutenção, sobrevivência e crescimento dos negócios.

Do ponto de vista do Marketing propõe-se que o cliente da Pousada, objeto deste estudo será tratado com cortesia. Os funcionários terão contato direto com os hóspedes e por isso deverão ser, necessariamente, solícitos, gentis e bem apresentados, proporcionando um ambiente familiar, que fuja da padronização dos hotéis, para isso deverão ser treinados e capacitados em curso de relações interpessoais oferecidos pela empresa. O quadro de funcionários deve contar com: camareiras, faxineiras, recepcionistas e gerente. Parte deles podem ser contratados como autônomos, trabalhando somente nos finais de semana e meses de pico.

Para manter o cliente fidelizado superando a concorrência será solicitado ao cliente/hóspede que responda um questionário para que se possa detectar e atendêlo cada vez melhor.

Será utilizado site na internet, propagandas na TV, folders que serão distribuídos nos pontos turísticos, out doors na estrada de Brasília/Alto Paraíso. 0 melhor Marketing é o de "boca-a-boca" o cliente que é fidelizado sempre volta e traz consigo outras pessoas.

\subsection{Recursos Financeiros}

São todos os gastos a serem realizados para a implantação da pousada com todos os bens físicos e mais as despesas realizadas no período da implantação. Essas despesas são chamadas de inversões fixas ou investimentos fixos. Para a pousada as inversões previstas são as relacionadas na Tabela 5.1 correspondente. O primeiro item do investimento fixo é o terreno onde será instalada a pousada. 
Deve ter uma área total de três a seis vezes maior que a área a ser construída. As construções civis são o segundo item do investimento fixo compreendem todas as despesas desde o projeto de engenharia e arquitetura, as obras preliminares, até as obras complementares para a entrega da obra concluída.

Deve-se contar com pessoas especializadas nas áreas de engenharia e arquitetura, para se ter ao final, uma construção adequada aos fins que se deseja.

Outro item dos investimentos fixos são os equipamentos e instalações próprios de uma pousada. São os equipamentos da cozinha, do bar, do restaurante e as instalações de água quente e fria, som e instalações telefônicas e de informática.

Mobília são todos os móveis que compõem os ambientes dos apartamentos, recepção, salão de espera, escritório, restaurante, bar e piscina. Utensílios são todos os materiais não duráveis que compõem os enxovais, as pratarias e a cutelaria. São bens que necessitam de reposição constante, por isso deve-se prever, nos custos, um valor percentual para renovação desses materiais. Os equipamentos de informática, compõem-se de hardware e software necessários às atividades do atendimento, caixa, faturamento, movimentação bancária, comunicação em geral e contabilidade da pousada.

O investimento feito em uma Pousada irá variar de acordo com a estrutura do empreendimento, já que neste tipo de negócio os valores dependem muito do porte. No caso do investimento inicial, muitas são as situações a considerar.

Antes de ser elaborado o quadro de investimento foram estudadas e relacionadas todas as despesas que a empresa deverá ter, inicialmente a empresa não terá funcionários esta será terceirizada, por isso os gastos com serviços de terceiros são representativos. Com certeza surgirão situações de gastos que não foram previstas, para isto foi reservada uma quantia para suprir os imprevistos.

A Tabela 5.1 mostra como os gastos com o investimento inicial são organizados. É recomendado que esta Tabela seja detalhada e atualizada de acordo com as despesas que forem ocorrendo, deixando a empresa cada vez mais inteirada dos aspectos reais do empreendimento nesta fase de estudo do negócio. 
Tabela 5.1

Investimento inicial

\begin{tabular}{l|l|l|l|l}
\hline \multicolumn{5}{c}{ INVESTIMENTO INICIAL - ANTES DA INAUGURAÇÃO (Valores em Reais) } \\
\hline \multicolumn{1}{c}{ Detalhamento } & $\begin{array}{c}\text { Desembolso } \\
\text { no 1ㅇ mês }\end{array}$ & $\begin{array}{c}\text { Desembolso } \\
\text { no 20 } \text { mês }\end{array}$ & $\begin{array}{c}\text { Desembolso } \\
\text { no 3ㅇ mês }\end{array}$ & \multicolumn{1}{c}{ Subtotal } \\
\hline Investimento em instalações & $5.000,00$ & $2.000,00$ & $1.000,00$ & $8.000,00$ \\
\hline Investimento equipamentos & $3.000,00$ & $1.000,00$ & $1.000,00$ & $5.000,00$ \\
\hline Investimento em Veículos & & & & \\
\hline Serviços de terceiros & $1.000,00$ & $1.000,00$ & $1.000,00$ & $3.000,00$ \\
\hline Mat. de consumo e utensílios & & & $2.000,00$ & $2.000,00$ \\
\hline $\begin{array}{l}\text { Gastos com a abertura da } \\
\text { empresa e inauguração }\end{array}$ & & & $2.000,00$ & $2.000,00$ \\
\hline $\begin{array}{l}\text { Reservas para gastos não } \\
\text { previstos }\end{array}$ & $3.000,00$ & & & $3.000,00$ \\
\hline Subtotal & $\mathbf{1 2 . 0 0 0 , 0 0}$ & $\mathbf{4 . 0 0 0 , 0 0}$ & $\mathbf{7 . 0 0 0 , 0 0}$ & $\mathbf{2 3 . 0 0 0 , 0 0}$ \\
\hline Reserva para capital de giro & & & $7.000,00$ & $7.000,00$ \\
\hline Total & $\mathbf{1 2 . 0 0 0 , 0 0}$ & $\mathbf{4 . 0 0 0 , 0 0}$ & $\mathbf{1 4 . 0 0 0 , 0 0}$ & $\mathbf{3 0 . 0 0 0 , 0 0}$ \\
\hline
\end{tabular}

A Tabela 5.1 representa um mapa orientador dos gastos iniciais. Dessa forma recomenda-se que esteja completa e bem detalhada, pois o quão mais detalhada ela esteja mais acertado será o planejamento. 


\subsection{Cronograma de Atividades}

\begin{tabular}{l|l|l|l|l}
\hline \multicolumn{1}{c}{ CRONOGRAMA DE ATIVIDADE - 2007 } \\
\hline ATIVIDADES & Fev & Mar & Abr & Mai \\
\hline Reforma & & & & \\
\hline Compra de equipamentos & & & & \\
\hline Vistoria & & & & \\
\hline Alvará de funcionamento & & & & \\
\hline Contração de Funcionários & & & & \\
\hline Treinamento de Funcionários & & & & \\
\hline Contratação de Serviços de terceiros & & & & \\
\hline Inauguração & & & & \\
\hline
\end{tabular}

O cronograma de atividades apresentado acima mostra como se dará a trajetória do empreendimento, desde a reforma até a inauguração. Primeiramente será feita uma reforma no imóvel adquirido, para que possa ser adaptado à realidade de uma pousada. Depois serão adquiridos os equipamentos necessários. Logo após será solicitado ao órgão competente a vistoria bem como o alvará de funcionamento.

Para seleção dos funcionários será colocado anúncio de contratação nos jornais de maior circulação. Após a seleção será feita uma entrevista selecionando os melhores candidatos para os cargos oferecidos. Em seguida os escolhidos farão o curso de relações interpessoais. Já com o quadro completo e os demais procedimentos aprovados será feita a inauguração, onde será oferecido um café. 


\section{DIMENSIONANDO O EMPREENDIMENTO}

A dimensão da Pousada, como qualquer empreendimento da área hoteleira deve levar em consideração, primordialmente, a quantidade de pessoas a ser atendida no estabelecimento. Portanto, ao se estudar o mercado, deve-se ter uma idéia quanto às possibilidades de demanda para a pousada.

Outro fator que se deve considerar é a capacidade de aporte dos recursos próprios e de terceiros. A pousada torna-se inviável por um tamanho que não leve em conta a disponibilidade dos recursos ou que não considere as expectativas da demanda.

Uma unidade hoteleira tem seu tamanho medido pelo número de suas unidades habitacionais, complementado com as dimensões totais da área construída, pois as áreas de apoio aos serviços, atendimento, lazer, recepção, lazer e piscina têm suas dimensões estabelecidas em função da quantidade de pessoas que deverão fazer uso das mesmas num determinado instante de utilização máxima.

Assim, a Pousada em estudo será dimensionada para que, com a lotação máxima das 20 unidades habitacionais, atenda sem atropelo a 40 pessoas em qualquer dos seus serviços, principalmente os de hospedagem e alimentação.

\subsection{Calculando a receita e os custos}

RECEITA DOS SERVIÇOS

$. R \$ 917.975,00$

a) Hospedagem $. R \$ 350.400,00$

Número de apartamentos/ chalés - 20 aptos. Duplos Taxa de ocupação média anual $60 \%$

Preço da diária $R \$ 80,00$

Receita da hospedagem $=20 \times 60 \% \times R \$ 80,00 \times 365=R \$ 350.400,00$ 
b) Alimentos / Bebidas $. R \$ 467.200,00$

Restaurante. $R \$ 350.400,00$

Número de pessoas presentes $-20 \times 60 \% \times 2=24$ pessoas

Comparecimento ao restaurante $-100 \%=24$ pessoas

Número de refeições diárias - 02 (almoço e jantar)

Despesa média por pessoa no restaurante $=R \$ 20,00$

Receita do restaurante $=24 \times 2 \times R \$ 20,00 \times 365=R \$ 350.400,00$

Bar $R \$ 36.500,00$

Comparecimento ao bar - 10 pessoas diariamente

Despesa média por pessoa no bar $=R \$ 10,00$

Receita do bar $=10 \times R \$ 10,00 \times 365=R \$ 36.500,00$

Copa / Frigobar $R \$ 26.280,00$

Despesa média diária por apartamento $=\mathrm{R} \$ 6,00$

Receita diária $=24 \times 60 \% \times \mathrm{R} \$ 6,00=\mathrm{R} \$ 72,00$

Receita anual da copa / frigobar $=R \$ 72,00 \times 365=R \$ 26.280,00$

\section{c) Outros serviços} $R \$ 100.375,00$

Lavanderia $R \$ 9.125,00$

Lavagem e engomagem de 10 peças por dia. Preço por peça $R \$ 2,50$

Receita da lavanderia $=10 \times R \$ 2,50 \times 365=R \$ 9.125,00$

Telefonia $\mathrm{R} \$ 18.250,00$

Estimativa de 10 ligações interurbana / dia. Preço médio da ligação $=R \$ 5,00$

Receita da telefonia $=R \$ 5,00 \times 10 \times 365=R \$ 18.250,00$

Passeio dos hóspedes $\mathrm{R} \$ 73.000,00$

Preço do passeio por pessoa $\mathrm{R} \$ 20,00.01$ passeio por dia com 10 pessoas

$R \$ 20,00 \times 10 \times 365=R \$ 73.000,00$

RECEITA ANUAL DOS SERVIÇOS DA POUSADA = R $\$ \mathbf{9 1 7 . 9 7 5 , 0 0}$ 


\subsection{Quantificação e Custo da Mão-de-Obra}

a) MÃO-DE-OBRA FIXA

Tabela 6.2

Mão-de-obra fixa

\begin{tabular}{|l|c|c|c|c|c|}
\hline \multicolumn{1}{|c|}{ Cargo } & Quant. & $\begin{array}{c}\text { Salário Médio } \\
\text { Mensal }\end{array}$ & $\begin{array}{c}\text { Salário } \\
\text { Anual }\end{array}$ & $\begin{array}{c}\text { Encargos } \\
\text { Sociais Anual }\end{array}$ & Total Anual \\
\hline Gerente & 01 & 800,00 & $9.600,00$ & $5.760,00$ & $15.360,00$ \\
Office-boy & 02 & 300,00 & $7.200,00$ & $4.320,00$ & $11.520,00$ \\
Telefonista & 01 & 300,00 & $3.600,00$ & $2.160,00$ & $5.760,00$ \\
Segurança & 02 & 350,00 & $8.400,00$ & $5.040,00$ & $13.440,00$ \\
Aux. manutenção & 01 & 500,00 & $6.000,00$ & $3.600,00$ & $9.600,00$ \\
Motorista & 02 & 400,00 & $9.600,00$ & $5.760,00$ & $15.360,00$ \\
\hline T o t a l & $\mathbf{0 9}$ & ----- & $\mathbf{4 4 . 4 0 0 , 0 0}$ & $\mathbf{2 6 . 6 4 0 , 0 0}$ & $\mathbf{7 1 . 0 4 0 , 0 0}$ \\
\hline
\end{tabular}

Encargos sociais calculados em $60 \%$ dos salários, por ser empresa optante do Simples. Auxiliar de manutenção: profissional para atender aos serviços de reparos das instalações d água, saneamento, instalações elétricas etc.

b) MÃO-DE-OBRA VARIÁVEL

Tabela 6.3

Mão-de-obra variável

\begin{tabular}{|l|c|c|c|c|c|}
\hline \multicolumn{1}{|c|}{ Cargo } & Quant. & $\begin{array}{c}\text { Salário Médio } \\
\text { Mensal }\end{array}$ & $\begin{array}{c}\text { Salário } \\
\text { Anual }\end{array}$ & $\begin{array}{c}\text { Encargos } \\
\text { Sociais Anual }\end{array}$ & Total Anual \\
\hline Recepcionista & 02 & 520,00 & $12.480,00$ & $7.488,00$ & $19.968,00$ \\
Cozinheiro & 01 & 600,00 & $7.200,00$ & $4.320,00$ & $11.520,00$ \\
Aux. de cozinheiro & 02 & 300,00 & $7.200,00$ & $4.320,00$ & $11.520,00$ \\
Camareira & 02 & 300,00 & $7.200,00$ & $4.320,00$ & $11.520,00$ \\
Lavadeira/passadeira & 01 & 300,00 & $3.600,00$ & $2.160,00$ & $5.760,00$ \\
Copeira & 01 & 300,00 & $3.600,00$ & $2.160,00$ & $5.760,00$ \\
Garçon & 03 & 300,00 & $10.800,00$ & $6.480,00$ & $17.280,00$ \\
Bar-man & 01 & 400,00 & $4.800,00$ & $2.880,00$ & $7.680,00$ \\
Aux. Serviços & 02 & 300,00 & $7.200,00$ & $4.320,00$ & $11.520,00$ \\
\hline T O T A L & 15 & ---- & $64.080,00$ & $38.448,00$ & $102.528,00$ \\
\hline
\end{tabular}


Encargos sociais calculados em $60 \%$ dos salários. Empresa optante pelo SIMPLES.

\subsection{Demais Custos Fixos}

\section{PRÓ-LABORE E ENCARGOS DA DIRETORIA}

Retirada mensal por sócio $=\mathrm{R} \$ 2.500,00$

Quantidade de sócios $=01$

Encargos sociais $=20 \%$ do pró-labore

$R \$ 2.000,00 \times 1 \times 12 \times 1,2=$ $\mathrm{R} \$ 28.800,00$

Tabela 6.4

Depreciação dos Bens do Imobilizado

\begin{tabular}{|l|c|c|c|}
\hline \multicolumn{1}{|c|}{ Item } & Valor & Índice & Custo \\
\hline Construções civis (1) & $360.850,00$ & 0,04 & $14.434,00$ \\
Veículos & $68.000,00$ & 0,20 & $13.600,00$ \\
Equipamentos e instalações & $45.420,00$ & 0,10 & $4.542,00$ \\
Móveis e utensilios & $72.794,00$ & 0,10 & $7.279,40$ \\
Equipamentos de informática & $7.500,00$ & 0,20 & $1.500,00$ \\
\hline T o t a l & - & - & $\mathbf{4 1 . 3 5 5 , 0 0}$ \\
\hline
\end{tabular}

Tabela 6.5

Manutenção

\begin{tabular}{|l|c|c|c|}
\hline \multicolumn{1}{|c|}{ Item } & Valor & Índice & Custo \\
\hline Construções civis (1) & $360.850,00$ & 0,02 & $7.217,00$ \\
Veículos & $68.000,00$ & 0,05 & $3.400,00$ \\
Equipamentos e instalações & $45.420,00$ & 0,05 & $2.271,00$ \\
Móveis e utensilios & $72.794,00$ & 0,10 & $7.279,40$ \\
Equipamentos de informática & $7.500,00$ & 0,05 & 375,00 \\
\hline T o t a l & - & - & $\mathbf{2 0 . 5 4 2 , 4 0}$ \\
\hline
\end{tabular}


Tabela 6.6

Seguro

\begin{tabular}{|l|c|c|c|}
\hline \multicolumn{1}{|c|}{ Item } & Valor & Índice & Custo \\
\hline Construções civis (1) & $360.850,00$ & 0,01 & $3.608,50$ \\
Veículos & $68.000,00$ & 0,05 & $3.400,00$ \\
Equipamentos e instalações & $45.420,00$ & 0,01 & 454,20 \\
Móveis e utensilios & $72.794,00$ & 0,01 & 727,94 \\
Equipamentos de informática & $7.500,00$ & 0,05 & 375,00 \\
\hline T o t a l & - & - & $\mathbf{8 . 5 6 5 , 6 4}$ \\
\hline
\end{tabular}

(1) Construções civis mais poço artesiano.

\section{MATERIAIS DE REPOSIÇÃO}

Cálculo de $10 \%$ sobre o valor dos utensílios para reposição após perda ou quebra.

$R \$ 12.250,00 \times 0,1=R \$ 1.225,00$

\section{FINANCIAMENTO DE LONGO PRAZO}

Valor do financiamento $=\mathrm{R} \$ 400.000,00$

Linha do financiamento - PROGER/ FAT/ BB

Taxa anual de juros $=5,33 \%$ aa

Custo anual do financiamento $=\mathrm{R} \$ 300.000,00 \times 5,33 \%=\mathrm{R} \$ 15.990,00$

\section{SERVIÇOS DE TERCEIROS}

Contador

Honorários anuais $=\mathrm{R} \$ 300,00 \times 12=\mathrm{R} \$ 3.600,00$ 


\section{OUTROS}

Estimativa de $1 \%$ sobre os demais custos fixos para maior segurança dos cálculos.

$\mathrm{R} \$ 191.117,64 \times 0,01=\mathrm{R} \$ 1.911,17$

CUSTO FIXO TOTAL

$. R \$ 193.028,81$

\subsection{Demais custos variáveis}

\section{ENERGIA ELÉTRICA}

A despesa média mensal de energia em Natal, em uma pousada de igual tamanho, está em torno dos $\mathrm{R} \$ 1.000,00$. Estima-se para a pousada de interior uma despesa média mensal com energia de $\mathrm{R} \$ 700,00$.

$R \$ 700,00 \times 12=R \$ 8.400,00$ anuais.

\section{MATERIAIS E MERCADORIAS}

a) Café da Manhã

Custo correspondente a $5 \%$ da receita com hospedagem $R \$ 350.400,00 \times 0,05$ $=R \$ 17.520,00$

b) Bebidas

Correspondente a $50 \%$ da receita com bebidas $=($ bar + copa/ frigobar $) \mathrm{R} \$$ $62.780,00 \times 0,5=\mathrm{R} \$ 31.390,00$

c) Alimentos

Correspondente a $40 \%$ da receita do restaurante $R \$ 350.400,00 \times 0,4=R \$$ $140.160,00$

d) Materiais de Limpeza

Estimada em $1 \%$ da receita bruta global $R \$ 917.975,00 \times 0,01=R \$ 9.179,75$

Total de Materiais e Mercadorias $=\mathbf{R} \$ 198.249,75$ 


\section{IMPOSTOS E TAXAS}

a) ISS - Cálculo de $5 \%$ sobre a receita bruta obtida com os serviços e hospedagem. Cálculo de $5 \%$ sobre hospedagem e serviços, exclusive receita do passeio dos hóspedes.

$R \$ 377.775,00 \times 0,05=\mathbf{R} \$ \mathbf{1 8 . 8 8 8 , 7 5}$

b) ICMS - Cálculo de $17 \%$ sobre o faturamento anual menos $13 \%$ sobre o mesmo faturamento, com alimentos e bebidas. ( $R \$ 467.200,00 \times 17 \%)(R \$ 467.200,00 \times$ $13 \%)=\mathbf{R} \$ \mathbf{1 8 . 6 8 8 , 0 0}$

c) IMPOSTOS FEDERAIS (PIS, COFINS E IMPOSTO DE RENDA).

Cálculo de 5,9\% sobre o faturamento bruto anual, conforme tabela de cálculo para as empresas optantes do SIMPLES. $\mathbf{R} \$ \mathbf{9 1 7 . 9 7 5 , 0 0 \times 0 , 0 5 9 = \mathbf { R } \$ \mathbf { 5 4 . 1 6 0 , 5 2 }}$

Total dos Impostos e Taxas $=\mathbf{R} \$ 91.737,27$

\section{COMISSÕES SOBRE O FATURAMENTO}

Valor estimado de $10 \%$ da receita bruta anual com hospedagem e alimentos e bebidas. $R \$ 817.600,00 \times 0,10=\mathbf{R} \$ \mathbf{8 1 . 7 6 0 , 0 0}$

\section{PROPAGANDA}

Custo limitado a $1 \%$ do faturamento bruto anual $R \$ 917.975,00 \times 0,01=R \$$ $9.179,75$

\section{LAVANDERIA}

Custo estimado em $30 \%$ da receita com lavanderia $R \$ 9.125,00 \times 0,3=R \$$ $2.737,50$

\section{COMBUSTÍVEIS E LUBRIFICANTES}

Despesa com a van - quilometragem/ dia $250 \mathrm{~km}$. km/ ano $91.250 \mathrm{Km} 91.250$ : $14 \mathrm{~km}$ por litro $\times \mathrm{R} \$ 1,60=10.428,57$ 
Despesa com o utilitário $=(25.000 \mathrm{Km}$ anuais $): 10 \mathrm{~km} / \mathrm{l}$ de gasolina $\times \mathrm{R} \$ 2,30=$ $\mathrm{R} \$ 5.750,00$. T o t a $\mathrm{I}=\mathrm{R} \$ 16.178,57$

\section{ÁGUA E ESGOTO SANITÁRIO}

Poço próprio. Esgoto sanitário próprio.

\section{TELEFONE/FAX/INTERNET COMUNICAÇÃO}

Custo estimado em 0,25 da receita com telefonia acrescido de $R \$ 300,00$ mensal para cobertura das despesas com fax e internet. $R \$ 18.250,00 \times 0,25+12 \times R \$$ $300,00=R \$ 4.562,50+R \$ 3.600,00=R \$ 8.162,50$

\section{OUTROS}

Estimativa de $1 \%$ calculado sobre os custos variáveis para segurança dos cálculos. $\mathrm{R} \$ 497.447,34 \times 0,01=\mathrm{R} \$ 4.974,47$

CUSTO VARIÁVEL TOTAL......................................R\$ 524.122,67

CUSTO TOTAL.....................................................R 717.151,48 


\subsection{Resumo dos Custos}

Tabela 6.7

Custos Fixos, Custos Variáveis E Custos Totais

\begin{tabular}{|l|c|c|}
\hline Discriminação & Valores em RS & $\%$ \\
\hline CUSTOS FIXOS & $193.028,81$ & $\mathbf{2 7 , 7 6}$ \\
\hline Mão-de-obra e encargos & $71.040,00$ & 10,21 \\
Pró-labore e encargos & $28.800,00$ & 4,14 \\
Depreciação & $41.355,00$ & 5,94 \\
Manutenção & $20.542,40$ & 2,95 \\
Seguros & $8.565,64$ & 1,23 \\
Materiais de reposição & $1.225,00$ & 0,17 \\
Financiamento de LP & $15.990,00$ & 2,29 \\
Serviços de Terceiros & $3.600,00$ & 0,51 \\
Outros & $1.911,17$ & 0.32 \\
\hline CUSTOS VARIÁVEIS & $\mathbf{5 0 2 . 4 2 1 , 8 1}$ & $7 \mathbf{7 2 , 2 4}$ \\
\hline Mão-de-obra e encargos & $102.528,00$ & 14,30 \\
Energia elétrica & $8.400,00$ & 1,17 \\
Materiais e mercadorias & $198.249,75$ & 27,66 \\
Impostos e taxas & $91.737,27$ & 12,79 \\
Comissões s/ faturamento & $81.760,00$ & 11,40 \\
Propaganda & $9.179,75$ & 1,27 \\
Lavanderia & $2.737,50$ & 0,38 \\
Combustiveis e lubrificantes & $16.178,57$ & 2,25 \\
Água e esgoto sanitário & - & \\
Telefone/ fax/ internet & $8.162,50$ & 1,15 \\
Outros & $5.189,33$ & 0,72 \\
\hline CUSTO TOTAL & $\mathbf{7 1 7 . 1 5 1 , 4 8}$ & $\mathbf{1 0 0 , 0 0}$ \\
\hline
\end{tabular}

\subsection{Calculando o Capital de Giro}

O capital de giro de uma pousada é composto dos valores rotativos que se renovam periodicamente durante o funcionamento da empresa. Concentra-se, basicamente, nos valores a receber das vendas a prazo, nos estoques de materiais e mercadorias e na disponibilidade mínima de caixa. O capital de giro possui dois 
grandes componentes: as necessidades e os recursos. $O$ valor dos recursos, subtraído do valor das necessidades, dá origem ao valor das inversões a serem feitas no capital de giro.

Tabela 6.8

Capital de Giro

\begin{tabular}{|l|c|c|c|}
\hline Discriminação & $\begin{array}{c}\text { Período } \\
\text { em dias }\end{array}$ & $\begin{array}{c}\text { Valores } \\
\text { Em rS }\end{array}$ & $\%$ \\
\hline NECESSIDADES DE GIRO & $05 \mathrm{dd}$ & $\mathbf{9 . 2 5 7 , 0 0}$ & $\mathbf{2 0 , 8 0}$ \\
1 - Encaixe mínimo & $15 \mathrm{dd}$ & $\mathbf{2 7 . 7 7 2 , 0 0}$ & $\mathbf{6 2 , 4 1}$ \\
2 - Crédito a receber & & $\mathbf{7 . 4 7 3 , 0 0}$ & $\mathbf{1 6 , 7 9}$ \\
3 - Estoques & $08 \mathrm{dd}$ & $3.072,00$ & - \\
$\quad$ 3.1 - De bens de consumo não duráveis & $30 \mathrm{dd}$ & $1.021,00$ & - \\
$\mathbf{3 . 2}$ - De materiais de reposição & $30 \mathrm{dd}$ & $3.380,00$ & - \\
$\quad$ 3.3 - De outros bens, inclusive os de consumo & & & \\
\hline duráveis & & $\mathbf{4 4 . 5 0 2 , 0 0}$ & $\mathbf{1 0 0 , 0 0}$ \\
\hline TOTAL DAS NECESSIDADES & $15 \mathrm{dd}$ & $\mathbf{8 . 2 6 0 , 0 0}$ & $\mathbf{1 8 , 5 6}$ \\
\hline 1 - Crédito dos fornecedores & - & - & \\
2 - Créditos bancários, inclusive cartão de crédito & $10 \mathrm{dd}$ & $\mathbf{4 . 4 2 8 , 0 0}$ & $\mathbf{9 , 9 5}$ \\
3 - Impostos e encargos sociais & $15 \mathrm{dd}$ & $\mathbf{4 . 4 5 8 , 0 0}$ & $\mathbf{1 0 , 0 2}$ \\
3 - Folha de pagamento dos salários & - & $\mathbf{1 7 . 1 4 6 , 0 0}$ & $\mathbf{3 8 , 5 3}$ \\
\hline TOTAL DOS RECURSOS & - & $\mathbf{2 7 . 3 5 6 , 0 0}$ & $\mathbf{6 1 , 4 7}$ \\
\hline CAPITAL DE GIRO & &
\end{tabular}

A pousada requer um investimento circulante no valor de $R \$ 27.356,00$, quando em seu funcionamento normal.

\subsection{Definindo o investimento total}

O investimento total da pousada compreende os gastos totais incluindo o investimento fixo mais o investimento circulante, isto é, o investimento fixo mais o capital de giro. Sua composição vê-se no quadro seguinte. 
Tabela 6.9

Investimento Total

\begin{tabular}{|l|c|c|c|c|c|c|}
\hline \multirow{2}{*}{ Discriminação } & \multicolumn{2}{|c|}{ Realizado } & \multicolumn{2}{c|}{ A realizar } & \multicolumn{2}{c|}{ T o t a l } \\
\cline { 2 - 7 } & Valor & $\mathbf{9}$ & Valor & $\mathbf{\%}$ & Valor & $\%$ \\
\hline 1- INVERSÓES FIXAS & - & - & $\mathbf{5 8 6 . 5 6 4 , 0 0}$ & $\mathbf{9 5 , 6 9}$ & $\mathbf{5 8 6 . 5 6 4 , 0 0}$ & $\mathbf{9 5 , 6 9}$ \\
Terreno & - & - & $20.000,00$ & 3,26 & $20.000,00$ & 3,26 \\
Construções civis & - & - & $350.350,00$ & 57,15 & $350.350,00$ & 57,15 \\
Equip. e instalações & - & - & $45.420,00$ & 7,41 & $45.420,00$ & 7,40 \\
Veículos. & - & - & $68.000,00$ & 11,09 & $68.000,00$ & 11,06 \\
Móveis e utensílios & - & - & $72.794,00$ & 11,88 & $72.794,00$ & 11,86 \\
Equip. de informática & - & - & $7.500,00$ & 1,22 & $7.500,00$ & 1,22 \\
Desp. de implantação & - & - & $12.000,00$ & 1,96 & $12.000,00$ & 1,96 \\
Outros (poço artesiano) & - & - & $10.500,00$ & 1,72 & $10.500,00$ & 1,72 \\
& & & & & & \\
2 INVERSÒES CIRCU & - & - & $\mathbf{2 7 . 3 5 6 , 0 0}$ & $\mathbf{4 , 4 6}$ & $\mathbf{2 7 . 3 5 6 , 0 0}$ & $\mathbf{4 , 4 6}$ \\
LANTES & & & & & & \\
Capital de giro & - & - & $\mathbf{2 7 . 3 5 6 , 0 0}$ & 4,46 & $\mathbf{2 7 . 3 5 6 , 0 0}$ & $\mathbf{4 , 4 6}$ \\
\hline T O T A L & & & $\mathbf{6 1 3 . 9 2 0 , 0 0}$ & $\mathbf{1 0 0 , 0 0}$ & $\mathbf{6 1 3 . 9 2 0 , 0 0}$ & $\mathbf{1 0 0 , 0 0}$ \\
\hline
\end{tabular}

Para atingir o nível das atividades previstas no estudo a Pousada requer um investimento total no valor de $\mathrm{R} \$ 612.963,00$. Como foi previsto um financiamento no valor $\mathrm{R} \$ 300.000,00$, cumpre ao empreendedor arcar com recursos próprios no valor de $R \$ 312.963,00$. 


\subsection{Analisando os resultados financeiros, econômicos e sociais}

Tabela 6.10

Resultados Financeiros, Econômicos e Sociais

\begin{tabular}{|c|c|c|}
\hline 1 - Receita bruta anual & $917.975,00$ & (1) \\
\hline 2- Impostos & $91.737,27$ & (2) \\
\hline 3 - Receita liquida anual & $826.237,73$ & $(1)-(2)$ \\
\hline 4- Custos variáveis & $432.385,40$ & Exclui impostos \\
\hline 5- Margem de contribuição & $393.852,33$ & $(3)-(4)$ \\
\hline 6- Custos Fixos & $193.028,81$ & $\overline{(6)}$ \\
\hline 7 - Lucro antes do IR e CS & $200.823,52$ & $(5)-(6)$ \\
\hline 8- Imposto de renda e contr. social & Optante do Simples & Incluido nos impostos \\
\hline 9- Lucro após o IR e CS & $200.823,52$ & $(7)-(8)$ \\
\hline 10 - Depreciação & $41.355,00$ & $(10)$ \\
\hline 11 - Capacidade para pagamento & $242.178,52$ & $(9)+(10)$ \\
\hline 12 - Período de retorno & 3 anos e meio & (Inv. Total):(9) \\
\hline 13 - Ponto de nivelamento & $49 \%$ & $(6):(5)$ \\
\hline 14-Rentabilidade & $32,6 \%$ & (9):(Inv. Total) \\
\hline 15 - Lucratividade & $21,8 \%$ & (9):(1) \\
\hline 16 - Receita total investimento total & 1,50 & (1):(Inv. Total) \\
\hline 17 - Receita total área construida & $\mathrm{R} \$ 1,008,76$ & $\begin{array}{l}\text { (1):(área de const. } \\
\text { civil) }\end{array}$ \\
\hline 18 - Investimento / emprego & $\overline{R S 25.580,00}$ & $\begin{array}{l}\text { (inv. Total):(n. } \\
\text { empregos) }\end{array}$ \\
\hline 19 - N. de empregos gerados & 24 & (19) \\
\hline $\begin{array}{l}20 \text { - Geração de impostos } \\
\text { p/o Estado } \\
\text { p/o Município } \\
\text { p/o Federal } \\
\end{array}$ & 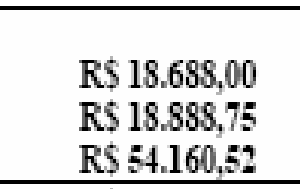 & \\
\hline 21-Renda bruta média p/ empregado. & RS $38.248,95$ & (1):(n. de empregos) \\
\hline
\end{tabular}




\section{FINANCEIROS}

O empreendimento da Pousada prevê um lucro líquido anual igual a $\mathrm{R} \$$ $222.524,38$, o que representa uma lucratividade de $24,2 \%$ ao ano. O investimento total vai gerar uma rentabilidade anual em torno dos $36,2 \%$.

A capacidade de pagamento no valor de $R \$ 263.879,38$, demonstra possibilidade de amortizar o financiamento de $R \$ 300.000,00$ em três anos, comprometendo apenas $38 \%$ de sua disponibilidade anual para pagamentos.

Trata-se, portanto, de um empreendimento que, do ponto de vista financeiro, tem sua efetivação recomendável. Seus resultados financeiros são substanciais, graças à opção feita pelo SIMPLES, o que Ihe permitiu uma redução nos custos dos encargos trabalhistas e nos impostos federais.

\section{ECONÔMICOS}

Todo o investimento realizado retornará em menos de três anos, um ótimo período de retorno para o tipo de empreendimento. Seu ponto de nivelamento está no nível dos $46,5 \%$ de sua capacidade de geração de receitas. Significa que acima desse nível a Pousada estará gerando lucro.

Esse percentual dá ao empreendedor uma margem de segurança de 53,5\% para geração de lucro. Temos, então um negócio seguramente viável, economicamente.

\section{SOCIAIS}

A Pousada gerará 21 empregos diretos e uma renda bruta anual por empregado, pró-investidor de $\mathrm{R} \$ 41.726,13$. Sua contribuição fiscal será de $\mathrm{R} \$ 18.888,75$ para o Município; $\mathrm{R} \$ 18.688,00$ para o Estado e $\mathrm{R} \$ 54.160,52$ em impostos Federais. 


\section{CONSIDERAÇÕES FINAIS}

Visando atingir os objetivos estabelecidos na seção 1 deste estudo foram apresentadas as principais ações necessárias para estruturar um Plano de Negócio, para empreender uma Pousada na cidade de Alto Paraíso. Foram apresentados também os passos para a sua elaboração, desde o Plano de Negócio até o cronograma das atividades.

O estudo permitiu constatar que é necessário planejar e fazer projeções, antes de executar o que se almeja com o empreendimento. Tais requisitos permitem dar uma melhor visão do futuro do negócio e uma maior chance de se obter êxito no empreendimento. O Plano de Negócios por sua vez, fornece uma visão da viabilidade do empreendimento, adequando-o melhor ao que se propõe.

As ações foram estruturadas em uma base sólida, uma vez que foi realizada pesquisa de campo em quatro hotéis/Pousadas da cidade das quais verificou-se a viabilidade de estruturar ou não uma Pousada na mesma cidade.

Os pontos que mais se destacaram foram a precariedade das estruturas das Pousadas visitadas, tendo-se verificado que, todas necessitavam de reformas, mesmo aquelas que não admitiam necessitar. As empresas têm mais de 5 anos na atividade e o preço que é cobrado pela estadia é alto diante do produto que é oferecido. É importante destacar que, apesar de algumas empresas não admitirem haver concorrência no mercado, o que foi observado pela pesquisa realizada é que há de fato.

Quanto ao grau de satisfação dos clientes foi detectado como ótimo, pois não se têm maiores opções fora as que já existem. Os clientes sempre retornam, pois o lugar é atrativo, as cachoeiras, os pontos turísticos, os passeios, mas não por serem os hotéis atrativos. Eles de fato deixam muito a desejar.

Referente à concorrência, as empresas se mostraram indiferentes, pois os hotéis não têm um diferencial que os destaquem uns dos outros. O diferencial ocorre mais por um ter estacionamento coberto, enquanto o outro não tem; por um ter restaurante enquanto o outro não tem. 
O que foi observado é que de fato não existe nenhum item que possa ser destacado como excepcional e que possa atrair o cliente para o hotel. Tal fato nos permite afirmar que a Pousada proposta neste estudo poderá entrar com destaque no mercado local.

Foi afirmado que o mercado turístico está crescendo, de fato, verificou-se que as Pousadas não conseguem acompanhar o mercado que é propenso ao crescimento. A maioria dos entrevistados considera a sua Pousada ótima, apesar de não demonstrarem total satisfação com seu empreendimento, porém não estão motivados em investir em outro tipo de negócio.

Foi observado também que falta ampliar os canais de divulgação, o que hoje estão limitados à internet e revistas. Existem outros canais tais como TV, jornal, folder e telemarketing.

Como o hotel produz basicamente serviço, entende-se que o seu produto é é basicamente todo o empreendimento, que deve ser cuidado em seus mínimos e importantes detalhes, pois esses podem fazer a diferença.

Através da pesquisa realizada, pode-se constatar que é viável empreender mais uma Pousada na cidade de Alto Paraíso e que ela representará um importante diferencial à concorrência, uma vez que se propõe a oferecer melhores produtos e serviços.

Finalmente, pode-se concluir que diante da concorrência atual, os empreendedores deveriam ter como foco as necessidades e expectativas dos clientes. É importante ressaltar que sem qualidade não há empreendimento que sobreviva. Neste sentido é necessário recorrer a profissionais qualificados que possam assessorar a empresa em suas diversas necessidades permitindo assim, um bom funcionamento e bons serviços prestados. 


\section{REFERÊNCIAS BIBLIOGRÁFICAS}

ACKOFF, Russel (1976). Planejamento empresarial. Rio de Janeiro: Livros Técnicos e Científicos.

BATISTA, Myriam V. (1981). Planejamento. Introdução a metodologia do planejamento social. São Paulo: Moraes

BELTRÃO, D. O. Turismo, A Indústria do Século XXI - Ática, São Paulo, 2001.

BUHALIS, D. Information tecnologyas a strategic tool for touriom. Tourism Review, n.2p. 34-36, 1996.

Brasil. Deliberação Normativa $387 / 98$ (revogada pela Deliberação Normativa 429/02)

CANDIDO, Índio. Governança em Hotelaria.ed. Hedus, 4ª̣ edição, 2001.

CASTELLI, G. Administração Hoteleira. 6ª . ed. Caxias do Sul: EDUCS, 1999.

DOLABELA, Fernando. Segredo de Luiza . São Paulo: Picture, 1999.

EcoTurismo: instrumento do desenvolvimento. Disponível em: http://www.aultimaa rcadenoe.com/instru.htm. Acesso em 10 de jun. 2007.

ENESTO, José. Gestão em Turismo e Hotelaria. São Paulo: Apleph. 2004

FILION, L. J. (1991). Visions et Relations: Clefs du Succes de L`entrepreneur. Montreal: Les Editions de Entrepreneur.

FREW, A. e PRINGLE, S. Multi-media Marketing across Atu Broadban Networks; a hospitality and tourism perspective (part 1). In: Proceegy Association Conference - New Orleans, Londres: HITA, 19

HOLANDA, Nilson (1985). Planejamento e elaboração de projetos. Rio de Janeiro, Mel / Fename. 
HORNADAY.J.A.(1982), Reserch about living entrepreneurs, Englewwod Cliffs, N.J.Prentice Hall, 1982, in Filion (1991).

IVES, B, \& LEARMONTH, G. Gan information technology revive yourbusines? Academy of Management Executive, 1990.

KOTLER, Philip. Administração de Marketing: análise, planejamento, implementação e controle. tradução Ailton Bomfim Brandão 5. ed. São Paulo: Atlas, 1998.

MANO, Cristiane. Cadê o plano? in Aponte o Rumo de Seu Negócio. Revista Exame Digital. Ano 34-n¹9-Edição 722-2000.

O CONNOR, P. Distribuição da informação eletrônica em Turismo e hotelaria. Bookman, 2001.Trigo, Luiz Gonzaga Godoi. Turismo Básico. São Paulo: SENAC, 2002

POON, A. (1993). Tourism, Technology, and Competitive Strategies. Cab Intern., Wallingford.

SEBRAE. Comece certo - Pousada. São Paulo, 1a edição: 2005.

TIMMONS, J. A HORNADAY A. - New Venture Creation : Entrepreneurship for the 21st. Century. 5th.Edition. Irvwin McGraw-Hill, 1999.

TRIGO, Mariana. Alto Paraíso, a capital do terceiro milênio. Editoria Férias Brasil: 2002

SCHUMPETER.J. A. (1934). The Theory of economic development. Havard University Press. 


\section{Apêndice A1}

Este apêndice apresenta o questionário que foi aplicado junto aos proprietários dos hotéis em Alto Paraíso - GO

\section{Questionário Aplicado}

LOCAL:-

ESTABELECIMENTO:-

INAUGURADO EM: ------/------/---------.

NÚMERO DE APARTAMENTOS-

PADRÃO:-

NOME DO ENTREVISTADO:-

FUNÇÃO DO ENTREVISTADO:-

DATA:-

1- Quais são seus principais concorrentes?

a)

b)

c)

d)

2- Que produtos e serviços eles oferecem além de hospedagem?

3- Quais os pontos fortes e fracos da sua Pousada?

Pontos fortes: 
Pontos fracos:

4- Que tipos de estabelecimentos seriam concorrentes de sua Pousada?

5- Qual o grau de satisfação dos clientes?
( ) Excelente
( ) Ótimo
( ) Bom
( ) Regular

6- Qual o grau de fidelidade dos seus clientes?
( ) Retornam sempre
$\%$
( ) Retornam ocasionalmente ----\%
( ) Não retornam -----\%

7- Qual seria a reação dos concorrentes a entrada de mais uma Pousada?
( ) Oposição forte
( ) Oposição média
( ) Oposição fraca
( ) Indiferença
( ) Apoio

8-O mercado turístico de Alto Paraíso se encontra em qual estágio?
( ) crescimento
( ) declínio
( ) estagnação

9-Tem idéia do faturamento de algum concorrente?
( ) Não

( ) Sim Quem ?

Quanto por mês ( media )

10-Como você analisaria a sua Pousada?
( ) Excelente
( ) Ótimo
( ) Bom
( ) Regular 
11-Qual o seu público - alvo; Exemplo: Jovens? Recém casados? Famílias? Idosos? Portadores de necessidades especiais? Entre outros.

12-Existe sazonalidade nas vendas? Quando? Como?

13-Qual o preço da sua hospedagem?

Há variação de preço ( Alta ou Baixa estação )?

14-Quais os principais canais de distribuição utilizados?

( ) Internet ( ) Jornal ( ) TV ( ) Folder ( ) Revistas

15-Quais as principais promoções utilizadas?

16-Quais são o faturamento e lucratividade da sua empresa?

17- Quanto tempo se passou da inauguração até o pagamento do investimento? 
Apêndice A2

Fotos de Alto Paraíso - GO

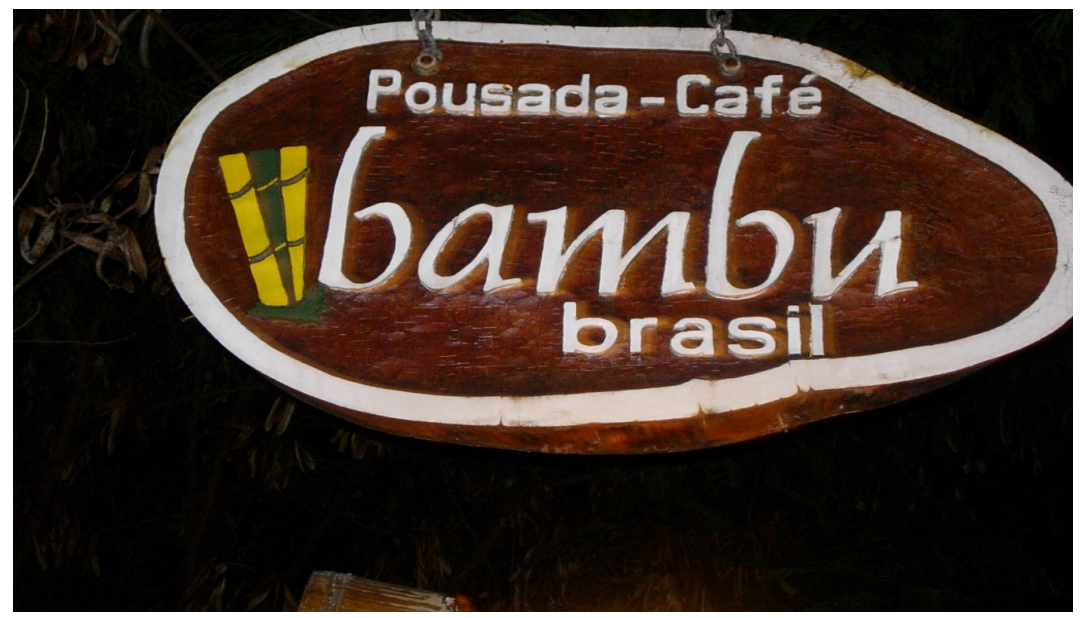

Fotos Daniel Calmon Pitanga

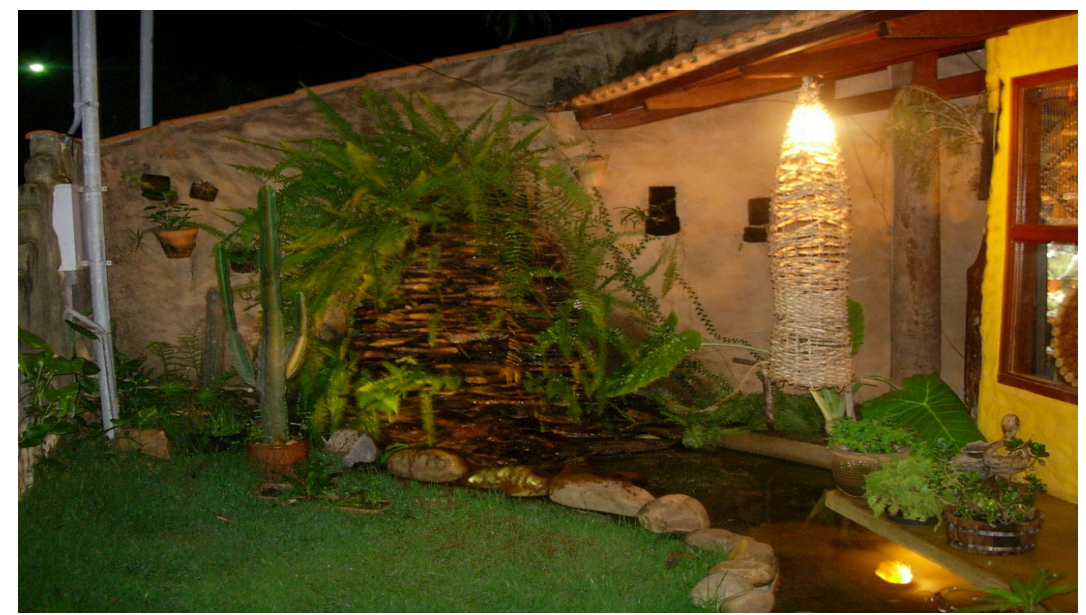

Fotos Daniel Calmon Pitanga

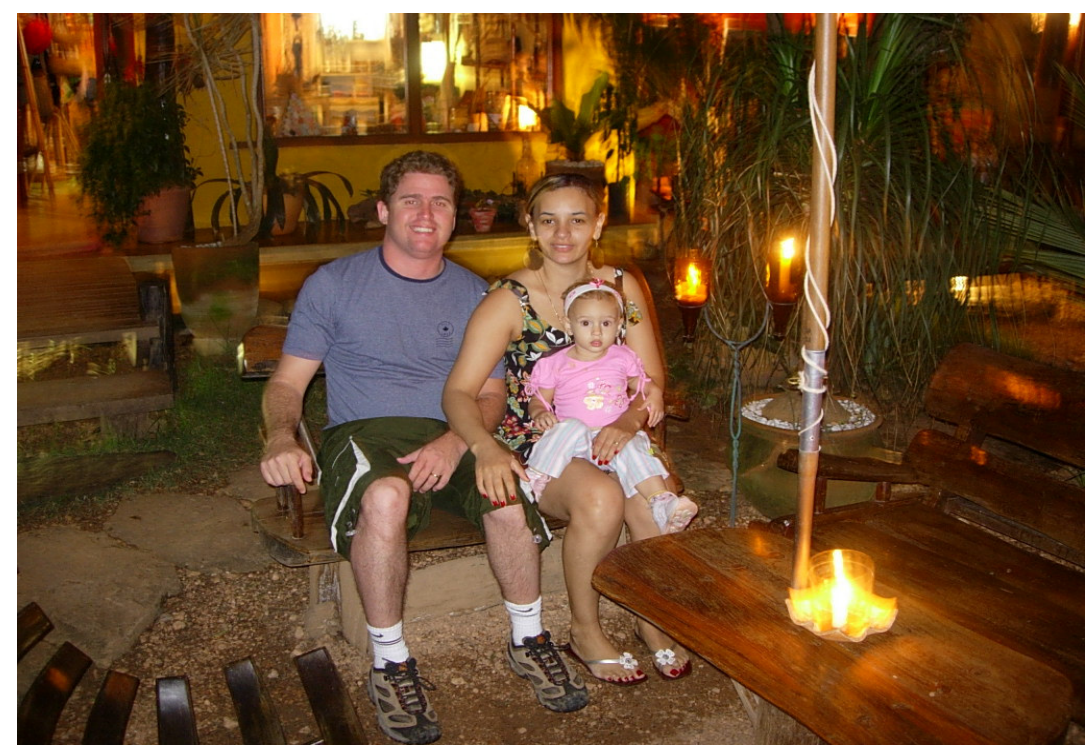

Fotos Daniel Calmon Pitanga 


\section{Anexo A3}

\section{Alto Paraíso, a capital do terceiro milênio}

O objetivo deste anexo é apresentar mais informações sobre a Cidade de Alto Paraíso, onde deverá ser construída a Pousada que fez parte do presente estudo.

\section{Alto Paraíso, a capital do terceiro milênio ${ }^{3}$}

O povoamento da região ocorreu com a implantação de uma fazenda na segunda metade do século XVII por Francisco de Almeida, passando a se constituir num pequeno núcleo de colonização, denominado Veadeiros, no qual foram agrupando lavradores. Nesta época radicaram-se também Firmino de Almeida Salermo, José Pereira Barbosa e Manuel Caboclo que se dedicaram à pecuária e ao cultivo do café. O clima e o solo da região demonstraram-se favoráveis ao cultivo do trigo e, segundo registros históricos, as primeiras sementes foram introduzidas por alguns egípcios que vieram da Bahia por volta de 1800.

O município é um dos mais apreciados cartões-postais de Goiás. A exuberante natureza esconde cenas quase mágicas, como o pôr do sol, as montanhas, os canyons, as cachoeiras, as minas de cristal, as flores do cerrado e a energia que emana do solo.

Em Alto Paraíso de Goiás estão instalados mais de 40 grupos místicos, filosóficos e religiosos sendo reconhecida pelos espiritualistas de todo mundo como uma das regiões do planeta destinadas a receber seres escolhidos pelos planos superiores da vida e que podem ser classificados com os artífices da Era de Aquário, Alto Paraíso se destaca no Brasil e no mundo como a Capital Brasileira do Terceiro Milênio. O paralelo 14 que atravessa a lendária cidade de Machu Pichu, no Peru, também passa sobre Alto Paraíso, em um local denominado Jardim Zen, onde pedras e flores compõem um cenário místico, originando fantásticas histórias sobre a região: discos voadores e seres extraterrestres.

\footnotetext{
${ }^{3}$ Estas informações foram escritas por Mariana Trigo pela Editora Férias Brasil
} 
O município possui uma crescente estrutura para o Turismo, com Pousadas, hotéis e áreas de camping, a cidade está a cerca de $1.300 \mathrm{~m}$. de altitude o que torna o clima bastante ameno.

Encontra-se no município de Alto Paraíso de Goiás no distrito de São Jorge, a porta de entrada do Parque Nacional da Chapada dos Veadeiros que foi criado através do Decreto Federal n. 49.875 em $11 / 01 / 61$, sendo sua área de 60.000 hectares, constitui-se em uma importante área, uma vez que existem muitas espécies ameaçadas de extinção, habitando a sua área.

Visitantes de todas as partes chegam até aqui atrás da maravilha selvagem e praticamente intacta do Parque Nacional da Chapada dos Veadeiros. O principal rio que corta o Parque Nacional é rio Preto, afluente do rio Tocantins, que comporta belíssimas cachoeiras e antigas formações rochosas que são consideradas uma das mais antigas do planeta, garantindo uma visão extasiante de pura beleza natural. Embora límpidas, suas águas são de uma tonalidade escura, que originou o nome do rio.

Ainda hoje encontramos dentro do parque, animais em processo de extinção, como o veado-campeiro, o lobo-guará, a capivara, as ágeis emas e os tucanos-de-bico-amarelo.

Fora do domínio do parque e ainda no distrito de São Jorge, encontramos o Vale da Lua onde o rio São Miguel corre entre rochas que impressionam pelas cores e pelas formas esculturais, talhadas pela força da água através dos tempos, o Espaço Infinito(Raizama), santuário de beleza selvagem, local bom para a prática do canyoning, em bela cachoeira no encontro entre os rios São Miguel e Raizama e a Morada do Sol, local onde há piscinas rodeadas por lages de pedras que formam cascatas, ideal para hidromassagem.

O Município de Alto Paraíso apresenta uma grande variação altimétrica, que vai de 600 até cerca de $1.676 \mathrm{~m}$, região esta denominada de Pouso Alto, sendo, portanto o ponto mais alto do estado de Goiás.

O artesanato mais importante atualmente na região de Alto Paraíso, é aquele ligado à confecção de arranjos decorativos com plantas regionais. Feitos principalmente com flores, frutos e sementes, e comercializados com o nome "Flores do Cerrado", esses arranjos dão empregos a diversas pessoas e chegam atingir o 
mercado externo. Podemos encontrar este e outros artesanatos regionais na Feira de Artesanato, as sextas, sábados, domingos e feriados, das 17:00 às 22:00 horas na Av. Ari Ribeiro Valadão Filho, ao lado do CAT.

A enigmática região de Alto Paraíso foi descoberta por grupos hippies e alternativos em 1964, atraídos pelo magnetismo de toneladas de cristais que repousam nestas terras e energizam esta fatia do Estado de Goiás. Nesta época, antes de ser batizada de Alto Paraíso, a cidade se chamava Cidade da

\section{Fraternidade}

Na década seguinte, este santuário ecológico e místico, que abriga dezenas de canyons, exuberantes cachoeiras, piscinas de águas naturais, minas cristalinas e uma fauna e flora ainda quase intocada pelo homem, viraram habitat de grupos exóticos e alternativos. Religiosos, filósofos, ufólogos e seguidores de seitas esotéricas instalaram mais de 40 comunidades espiritualistas, que recebem vibrações do paralelo 14, o mesmo que atravessa a lendária cidade Inca de Machu Pichu, no Peru.

A uma distância de 412 km de Goiânia, o capital do Estado, Alto Paraíso tornou-se uma espécie de chácara do país, um dos berços da Nova Era, a consciência da preservação ecológica.

É considerado o santuário Goiano do misticismo, esoterismo e espiritualismo. Atravessada pelo Paralelo 14, da mesma forma que Machu Pichu, no Peru, proporciona fantásticas histórias sobre discos voadores e seres extraterrestres.

Além do esoterismo, a cidade é propícia para o ecoTurismo, visto que sua população tem uma consciência ecológica muito desenvolvida, e a natureza local é exuberante, com centenas de atrações dentre cachoeiras, vales, serras, fazendas, onde o acesso a esses locais se dá de automóvel até um certo ponto e depois caminhadas que podem variar de 300 metros a $10 \mathrm{~km}$, porém todas inesquecíveis por sua beleza e magia. A cidade conta com uma infra-estrutura voltada para o Turismo, oferecendo Pousadas, hotéis fazenda, restaurantes, bares, pizzaria, venda de artesanato e um Centro de Atendimento a Turistas onde você encontra guias cadastrados que os conduzirão aos passeios. Além do Aeroporto próximo à cidade 
que oferece inesquecível visão do mais belo pôr do sol da região. Tanto misticismo fez com que a cidade se transformasse num crescente pólo de Turismo alternativo internacional. Visitantes dos quatro cantos do planeta vêm para cá atraídos não só pela cidade construída sobre minas de cristais, mas pelo paraíso ecológico que é o Parque Nacional da Chapada dos Veadeiros, a 39 km de Alto Paraíso.

\section{Como chegar a Alto Paraíso Goiás (GO)}

- Carro: partindo de Brasília, pegue a BR-020 e GO-118. São 222 km até Alto Paraíso.

- Ônibus: há linhas diárias partindo da rodoviária de Brasília até Alto Paraíso.

- Na rodoviária de Alto Paraíso (62 765-9876), existe um ônibus que leva os visitantes para o Povoado de São Jorge, portal de entrada para a Chapada dos Veadeiros. Alto Paraíso conta com uma Central de Atendimento ao Turista (62 446-1159)

\section{Mapa de Alto-Paraíso}

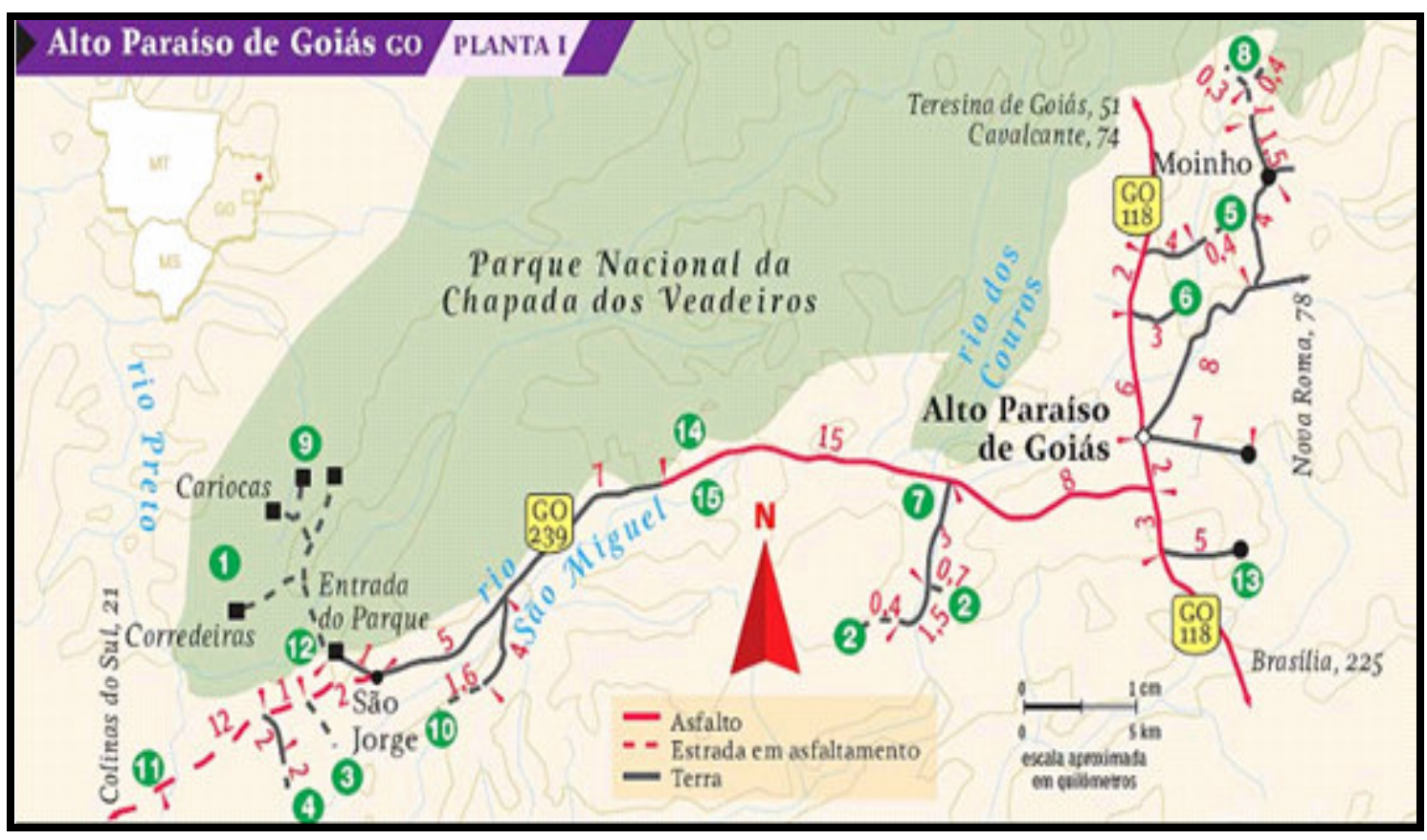


Nos primeiros dias, os visitantes ficam extasiados com a generosidade de riquezas naturais. São centenas de cachoeiras, vales, fazendas, serras, canyons, rochas, nascentes e minas de cristais.

Pela abundância destas pedras que chegam a ofuscar os turistas, o pequeno povoado de São Jorge reserva em seu passado o marco de ter sido uma zona de garimpo. Com a criação do parque da Chapada e a extinção da exploração das minas, os garimpeiros tornaram-se guias turísticos e contadores de histórias. Contrate um deles (62 446-1690 / 446-1159) para conhecer melhor a região. Dentre outras atrações, eles irão te apresentar ao enigmático Vale da Lua. Rochas esculpidas pela natureza, mirantes e poderosas piscinas naturais de águas cristalinas fazem deste lugar um cenário único com uma energia intrigante, onde muitos acreditam ser uma passagem para outra dimensão.

Pelo caminho, a fauna e a flora bordam cenários dignos de telas surrealistas. Não deixe de conhecer as cachoeiras do Rio Cristal, as piscinas naturais da Fazenda São Bento, o Jardim de Maytrea, o Morro da Baleia, o Poço Encantado, a Cachoeira São Vicente, a Vila Colonial de Moinho e as cachoeiras do Anjo e do Arcanjo. Também visite as Cachoeiras Almécegas, com uma refrescante queda de $60 \mathrm{~m}$ de altura. Porém, o melhor está por vir: os audaciosos Saltos do Rio Preto, com $120 \mathrm{~m}$ e $80 \mathrm{~m}$ de altura separada entre si por $300 \mathrm{~m}$, arremessam águas translúcidas pelos ares e se transformam num inacreditável espetáculo da capital do terceiro milênio.

No dia seguinte, se prepare para um longo passeio. Você pode conhecer a Serra dos Topázios (62 274-0461), uma Reserva Particular do Patrimônio Natural, diplomada pelo IBAMA. Ela é considerada o paraíso energético da região dos cristais e abriga 500 hectares de cachoeiras, cerrado nativo e uma fauna e flora que mais parecem um Simba Safári. Outro passeio imperdível é visitar a cidadezinha de São Domingos, na divisa entre Goiás e Bahia. Ela é o território brasileiro com o maior potencial para a exploração de cavernas. Aqui, quilômetros de cavernas banhadas por rios subterrâneas e lindas cachoeiras expõem o exotismo da região.

Mas, apesar da sintonia com a Era de Aquários, a cidade, com 6.000 habitantes, conta com uma boa infra-estrutura para receber os visitantes. As ruas são asfaltadas, existem ótimos restaurantes, Pousadas aconchegantes, hotéis, 
pizzarias e até alguns barzinhos noturnos que tentam agitar os aficionados por mantras.

$\mathrm{Na}$ hora de escolher um bom restaurante, não hesite em entrar no clima natureba e aproveitar para mudar seus hábitos alimentares, ingerindo alimentos mais saudáveis. Para isso, o Restaurante Jambalayba, na Rua Coleto Paulino, 522, dispõe de um menu com muitas saladas, verduras cozidas, arroz integral, sucos e carnes. Outro restaurante que segue a mesma linha é a Arte de Comer (62 4461779), que tem como atrativo a deliciosa comida caseira, isenta de gorduras e frituras. Mas, se este cardápio é sinônimo de tortura, e parece estar longe do prazer de comer, não se preocupe. Você não é obrigado a entrar na dieta. Que tal um crepe? A Creperie Alfa \& Omega (62 446-1163) é especializada em vários sabores, alguns até exageradamente calóricos, mas deliciosos.

Antes de pensar em arrumar as malas e se despedir de Alto Paraíso, não se esqueça das compras, que transbordam em produtos místicos. Comece pela loja Roberto dos Cristais (62 446-1668) e Canto das Fadas (62 446-1708), que vendem cristais e pedras como topázio, ametista, ágata e muitos quartzos. Para ir saboreando Alto Paraíso até chegar em casa, passe no Senhor Waldomiro, no Morro da Baleia (estrada p/ São Jorge, km 19) e compre doces de frutas da região, licores, biscoitos, geléias, pingas e outras delícias. Depois, conheça o Tom das Ervas (62 446-1588), que vende óleos vegetais, buchas, pomadas, raízes, ervas de todos os tipos, xaropes e licores.

Depois de tudo pronto, não deixe de dar uma última volta por este templo a céu aberto. Repare nas pessoas que largaram tudo para viverem de um jeito simples, em pura comunhão com a natureza.

Aqui, eles passam a noite a observar uns céus infinitamente estrelados em busca de óvnis, comem alimentos sem agrotóxicos, cantam mantras, difundem a paz, produzem artesanatos, nadam nos rios, caminham nas matas, reverenciam as nascentes, respondem perguntas dos curiosos e se traduzem em gente simples, que se alimenta e retira forças destas pedras milenares. Eles abandonaram o conforto urbano, o high tech, a tela plana, o celular, os eletrodomésticos e os laptops de última geração. Porém, não deixaram de estar conectados com o mundo, mas de outra forma. Aqui, eles acessam o site das nascentes e navegam pelo terceiro milênio em busca de equilíbrio, harmonia e evolução espiritual. 
Bibliografia: Alto Paraíso, a capital do terceiro milênio

\section{Calendário de Feriados Municipais:}

15 de Agosto - Nossa Senhora da Abadia

27 de Novembro - Nossa Senhora das Graças, Padroeira da cidade.

12 de Dezembro - Aniversário de emancipação da cidade.

\section{Outros Eventos:}

22 de Abril - Festa no Distrito de São Jorge

50 dias após a Páscoa - Festa do Divino Espírito Santo

Junho - Festa Junina

Julho - Moonstock - Festival de Inverno

Setembro - Campeonato Brasileiro de Pólo Aquático em Águas Correntes 


\section{Principais Pontos Turísticos}

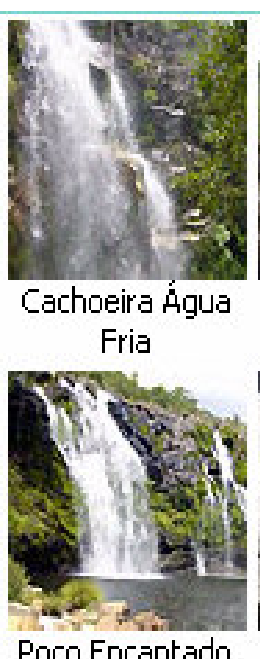

Poço Encantado

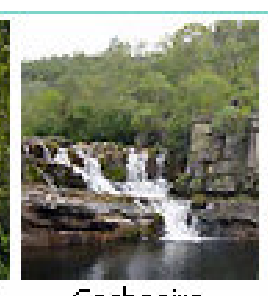

Cachoeira Almécegas

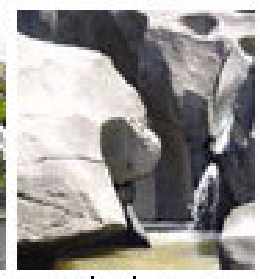

Vale da Lua

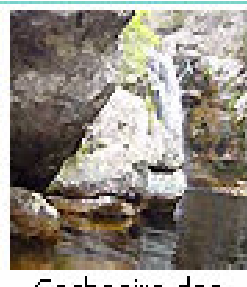

Cachoeira dos Anjos e Arcanjos

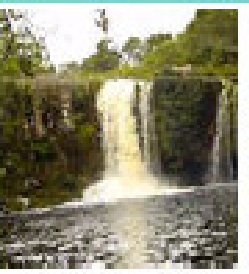

Cachoeira São Bento

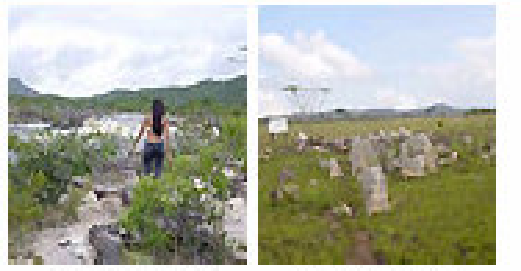

Corredeiras

Jardim Zen

\section{Cachoeira da Água Fria}

É uma queda com total de $190 \mathrm{mts}$.em cascatas que variam entre 60,50 e $30 \mathrm{mts}$. de altura com grandiosa vista para o Vale do Moinho, ideal para a prática de Rappel. Encontra-se no Camping Santa Rita de Cássia a $08 \mathrm{Km}$ da cidade de Alto Paraíso (Bom para pessoas da Melhor Idade)

\section{Cachoeiras Almécegas I e II:}

Cai em forma de véu de noiva, a $45 \mathrm{mts}$. De altura. Sua piscina tem águas verdes cristalinas e o córrego Almécegas vai além por um grande canyon de rochas colorida. Encontra-se no Hotel Fazenda São Bento a $08 \mathrm{Km}$ da cidade de Alto Paraíso.

\section{Cachoeira do Macaco}

O rio Macaco forma um belíssimo complexo de cachoeiras, existe na região uma comunidade a Aldeia Arco-Íris, que oferece infra-estrutura de alojamento e alimentação para visitantes. Fica à $40 \mathrm{Km}$ de Alto Paraíso 


\section{Cachoeira São Bento}

É a primeira das grandes cachoeiras formadas pelo rio dos Couros e possui uma ótima piscina natural para mergulho e natação, em uma das margens há uma caverna semi-submersa. No mês de setembro sedia campeonatos de Pólo-Aquático. A $08 \mathrm{Km}$ de Alto Paraíso (Bom para pessoas da Melhor Idade)

\section{Distrito de São Jorge}

Porta de entrada para visitação ao Parque Nacional da Chapada dos Veadeiros. Conta com uma população voltada para o EcoTurismo. Fica a $38 \mathrm{Km}$ de Alto Paraíso.

\section{Jardim de Maytrea}

Também é um local valorizado por espiritualistas que afirmam existir no local um capo de força magnética. A $20 \mathrm{Km}$ de Alto Paraíso pela Estrada Parque

\section{Jardim Zen}

Pedras e flores compõem o cenário deste místico ponto por onde passa 0 Paralelo 14 - a mesma linha que corta Machu Pichu, no Peru. Localizado no Pouso Alto às margens da Rod. GO-118 à 17 Km de Alto Paraíso

\section{Mirante do Baliza}

Local da antiga antena de TV, chegando a ter $1.494 \mathrm{mt}$. de altitude e com quase $360^{\circ}$ de visibilidade. É um divisor de águas onde encontramos o Cerrado de Altitude com espécies endêmicas.

\section{Mirante do Pouso Alto}

Monumento símbolo do ponto mais alto do Estado de Goiás - o morro do Pouso Alto com 1.676 metros. 


\section{Morada do Sol}

Piscinas rodeadas por lages de pedras que formam cascatas, ideal para hidromassagem. Fica a $06 \mathrm{Km}$ após o Distrito de São Jorge (Bom para pessoas da Melhor Idade)

\section{Morro da Baleia}

É um local estimado pelos espiritualistas, que realizam em seu topo vigílias, celebrações e meditações. Perfeito para caminhadas, com águas para banhos no alto do primeiro platô em certas épocas do ano. A $18 \mathrm{Km}$ de Alto Paraíso pela Estrada Parque

\section{Parque Nacional da Chapada dos Veadeiros}

Unidade de Conservação abrangendo um terço da área do município de Alto Paraíso de Goiás. Possui lindo atrativo turístico como: Saltos do Rio Preto (Cachoeiras de 80 e $120 \mathrm{mts}$ ), Corredeiras, Canyons e Cariocas, cujo acesso se faz a pé a partir do Distrito de São Jorge.

\section{Povoado do Moinho}

Fica num grande e fértil vale entre os contrafortes da Serra Geral do Paranã e a Serra da Água Fria, a $12 \mathrm{Km}$ de Alto Paraíso. Conta com o Parque Solarion com as cachoeiras dos Anjos e Arcanjos e o Sítio Flor de ouro.

\section{Raizama}

Santuário de beleza selvagem, local bom para a prática do canyoning, em bela cachoeira no encontro entre os rios São Miguel e Raizama, mas perigoso na época de chuva. À 05 km do Distrito de São Jorge 


\section{Rio Cristal}

Várias cachoeiras pequenas e charmosas, com diversos recantos para tomar uma boa ducha natural e banho de sol. A $08 \mathrm{Km}$ de Alto Paraíso. (Bom para pessoas da Melhor Idade)

\section{Vale da Lua}

O rio São Miguel corre entre rochas que impressionam pelas cores e formas esculturais, talhadas pela força das águas através dos tempos. A $05 \mathrm{Km}$ antes do Distrito de São Jorge. (Bom para pessoas da Melhor Idade).

As taxas de entrada dos atrativos variam de $R \$ 3,00$ a $R \$ 5,00$

A visita ao Parque Nacional da Chapada dos Veadeiros \{(61) 646-1570\}, só é permitida com acompanhamento de um Guia credenciado pelas Associações:

ACVCV- Associação dos Condutores de Visitantes da Chapada dos Veadeiros \{Tel.: (61) 646-1690\}

SERVITUR - Associação de Prestadores de Serviços em EcoTurismo- \{Tel. (61)646-1235\}

O Parque fecha às segundas-feiras para manutenção interna.

\section{ONDE FICAR EM ALTO PARAÍSO}

\section{Pousadas:}

Alfa e Ômega - 646-1225 (www.persocom.com.br/paraíso)

Aquarius - 646-1952 / 9978-9438

Arco-Íris-646-1200 (arcoiris@solar.com.br)

Branca - 646-1950

Camelot Inn-646-1581/646-1449 (www.Pousadacamelot.com.br)

Campestre - 646-1231 
ChácaraＡnos-luz-9978-9839/646-5(anosluz@uol.com.br)

(www.tba.com.br/pages/prtchapada)

Chácara Vitória - 646-1374

Do Sol - 646-1201

Estrela do Oriente - 646-1853

La Mandarina - 646-1474 - Reservas pela Alpatur - 646-1820 ou 646-1821

(www.altoparaiso.com/lamandarina)(lamandarina@altoparaiso.com)

Menina Lua - 646-1177 / 646-1214

\section{Hotéis}

Central - 646-1486

Europa-646-1558 (hoteuropa@tba.com.br)(www.listel.com.br)

Nunes - 646-1401

Tradição - 646-1202

\section{Hotéis Fazenda}

Pousada dos Anões - 508-3232 / 508-3333

São Bento - 646-1268 / 9978-8265

(www.Pousadasaobento.com.br)(saobento@Pousadasaobento.com.br

Fazenda Osho Lua - 646-1613 / 646-1562

\section{Camping}

Mãe Natureza - 9961-6321 / 646-1648

O Canto do Cerrado - 646-1522

Peskero - À $13 \mathrm{Km}$ de Alto Paraíso

Portal (Camping e Chalés - 9955-0627 (Paulo)).

Portal da Chapada - 9978-9398

Quarto Crescente - 646-1508

Santa Rita de Cássia (Fazenda Água Fria)- 9955-9214 / 552-3151 
Solarion - Moinho

Vale Azul - 646-1434

\section{RESTAURANTES , LANCHONETES E PIZZARIAS EM ALTO PARAÍSO}

Bom Fass Bar

Av. Ari Ribeiro. Valadão Filho 646-1336 Responsável: Átila Damasceno

Cachorro Quente do Valderi (Recanto da Fogueira

Av. Ari Ribeiro Valadão Filho 646-1623 Responsável: Valderi e Dejanira

Churrascaria Espeto do Sul

GO 118 Km 167 - Str. Planalto 646-1729 Responsável: Andréia e João Carlos

spetodosul@tba.com.br

Clube da Esquina

Av. Ari R.V. Filho 9996-8702 Responsável: Dra.Vera

Creperiê Alfa e Ômega

Av. Ari Ribeiro Valadão Filho 646-1163 Responsável: Luis Paulo / Paula Igreja Brito

Kahuna Café

Espaço Gama Brasil - Av. Ari Ribeiro

Valadão Filho,1035 646-1790 Responsável: Zé Antônio

Lanchonete Erva Doce

Av. Ari R. V. Filho, Responsável: Wanderlei e Maricélia

Especialidade: Caldos

Lanchonete da Rodoviária

Praça Ely Paulino da Silva646-1359 Responsável: Sirley Alves Machado (Leila)

O Canto das Fadas

Av. Ari Ribeiro Valadão Filho $\quad 9904-8840$ Responsável: Davi e Apsara

Pizza 2.000

Av. Ari Ribeiro Valadão Filho 646-1814 Responsável: Ana Maria

Restaurante Bicho Papão

Av. Paraíso 646-1777 Welcome

Restaurante Casa da Mama

R. São José Operário em frente ao Hospital Municipal 646-1362

Responsável: Sr. Giovanni e Dna. Damiana

Restaurante Central 
Av. Ari Ribeiro Valadão Filho no Hotel Central 646-1486 Responsável: Francisco Gonzaga (Paulo) / Dazinha

Restaurante Estrela do Oriente

Av. Paraíso 646-1853 Responsável: Dona. Nenzinha

Restaurante do Jatô

Rua Palipalã 646-1339 9972-5037Responsável: Jatô e Luiz

jatô@mymail.com.br

Restaurante Jambalaya

Estância Paraíso em frente a Pousada do Mirante 9973-5501

Responsável: Renato e Nives

Restaurante Paladar

Av. Paraíso 9995-3613 Responsável: Eurídice 